\title{
7. ANALYSIS OF SEDIMENTARY FACIES, CLAY MINERALOGY, AND GEOCHEMISTRY OF THE NEOGENE-QUATERNARY SEDIMENTS IN SITE 645, BAFFIN BAY1
}

\author{
F. Thiébault, ${ }^{2}$ M. Cremer, ${ }^{3}$ P. Debrabant,${ }^{2}$ J. Foulon, ${ }^{2}$ O. B. Nielsen, ${ }^{4}$ and H. Zimmerman ${ }^{5}$
}

\begin{abstract}
Subcontinuously cored early(?)-middle Miocene to recently deposited sediments from ODP Site 645 were studied texturally, mineralogically, and geochemically. The entire sequence contains minerals and associated chemical elements that are chiefly of detrital origin. In particular, the clay minerals, which include smectite, kaolinite, chlorite, and illite, are detrital. No obvious evidence of diagenesis with depth, of burial, of volcanism, or of hydrothermal alteration was observed.

The sedimentary textures, clay mineralogy, and $<2-\mu \mathrm{m}$ fraction geochemistry of the early middle Miocene sediments ( 630 to 1147 mbsf) suggest the pronounced but variable influence of a southward bottom current. Two clay facies are defined. The lower one, $C_{1}$ ( 780 to $1147 \mathrm{mbsf}$ ), is characterized by the great abundance of discrete smectite (with less than $15 \%$ illite interlayers), probably detrital in origin, and reworked older, discrete, smectite-rich sediments. The upper clay facies, $C_{2}$ (630 to 780 mbsf), shows a net decrease of the fully expandable clay abundances, with a great abundance of mixed-layer, illite-smectite clays (60 to $80 \%$ of illite interlayers). Such clay assemblages can be inherited from paleosoils or older sedimentary rocks.

An important change occurs at 630 mbsf (clay fraction) or $600 \mathrm{mbsf}$ (sedimentary texture), which may be explained by the beginning of continental glaciation $(630 \mathrm{mbsf}, \sim 9 \mathrm{Ma})$ and the onset of ice rafting in Baffin Bay $(600 \mathrm{mbsf}, \sim 8$ Ma).

Above this level, the characteristics and modifications of the clay assemblages are controlled climatically and can be explained by the fluctuations of (1) ice-rafting, (2) speed of weak bottom currents, and (3) some supply by mud turbiditic currents. Three clay facies $\left(C_{3}, C_{4}\right.$, and $\left.C_{5}\right)$ can be defined by the abrupt increases of the inherited chlorite and illite clays.
\end{abstract}

\section{INTRODUCTION}

An important objective of Leg 105 of the Oceean Drilling Program (ODP) was to investigate the paleoceonographic changes in the climatically sensitive high-latitude region of Baffin Bay. This study focuses on the Neogene paleoceanographic history of this small ocean basin (Gradstein and Srivastava, 1980) as inferred from the depositional history and clay mineral assemblages.

Previous work in this region was restricted to (1) shallow exploratory drill holes (Mac Lean, 1978; Mac Lean and Falconer, $1977,1979)$ that provided stratigraphic information about the continental shelf history and (2) surficial and piston-core sediment studies (Piper and Slatt, 1977; Kravitz, 1982; Aksu, 1983) that provided information about late Quaternary sedimentary processes.

During Leg 105, seven holes were drilled in water $2020 \mathrm{~m}$ deep at Site 645 (Fig. 1). In Holes 645B, 645D, and 645E, we penetrated a nearly complete early Miocene to Holocene section $1147 \mathrm{~m}$ thick and recovered $66 \%$ of this section. This sequence contains few fossils. Precise age assignments were difficult because of fossil scarcity and evidence of old fossils reworked into younger sediments. Ages were determined from dinocysts, benthic foraminifers, pollen, a few calcareous nannofossils, and magnetostratigraphy (Fig. 2).

\footnotetext{
${ }^{1}$ Srivastava, S. P., Arthur, M., Clement, B., et al., 1989. Proc. ODP, Sci. Results, 105: College Station, TX (Ocean Drilling Program).

2 Laboratoire de Dynamique Sédimentaire et Structurale, UA CRNS 719, UFR des Sciences de la Terre, Université de Lille-Flandres-Artois, 59655 Villeneuve d'Ascq Cedex, France.

${ }^{3}$ Département de Géologie et Océanographie, Université de Bordeaux I, Avenue des Facultés, 33405 Talence Cedex, France.

${ }^{4}$ Department of Geology, Aarhus University, DK-8000 Aarhus C, Denmark.

5 Division of Polar Programs, National Science Foundation, Washington, DC 20550.
}

On the basis of shipboard core descriptions, three main lithologic units were recognized at Site 645 (Fig. 2). The sediments have a pronounced terrigenous character and range from muddy sands and muddy silts to clayey silts. Coarse particles up to cobble size are present in both lithologic Units I and II and are minor in lithologic Subunit IIIA. Two major reflectors were identified: $R_{1}$ near the top of lithologic Unit III and $R_{2}$ at the boundary of lithologic Subunits IIIB and IIIC. Regional seismic data, sedimentary textures, and structures (Srivastava, Arthur, et al., 1987) indicate that deep contour-following currents were a dominant transport process during early-middle Miocene, while ice rafting became prevalent from late Miocene.

Here, we describe and interpret the conditions of Neogene sedimentation in Baffin Bay by sedimentalogical, mineralogical, and geochemical investigations of Site 645 materials. In the following section, we outline the methods of sample analyses and then present and interpret the results of grain-size, clay mineralogy, and geochemical analyses.

\section{METHODS}

An average of one $20-\mathrm{cm}^{3}$ sample per core was collected from dominant lithologies throughout Site 645. The same samples were used for grain-size and mineralogical studies as much as possible. Additional texture analyses were conducted using $50-\mathrm{cm}^{3}$ samples (see Cremer, this volume). The following analyses were conducted:

1. Grain-size analyses of 118 samples.

2. Mineralogy by X-ray diffraction of clay fraction of 115 samples.

3. Geochemistry of the $<2-\mu \mathrm{m}$ fraction of 32 samples (Table 1).

4. Semiquantitative analysis with Camebax microprobe on simple clay mineral assemblages of five samples (Table 2).

5. Geochemistry on whole-rock (10) samples (Table 3).

\section{Grain-Size Analyses}

Because of the scarcity of biogenic components in the sediments, the bulk samples were used to determine grain-size distribution. The $>63$ $\mu \mathrm{m}$ fraction was dry sieved using $100-, 160-, 250-$, and $400-\mu \mathrm{m}$ diameter 


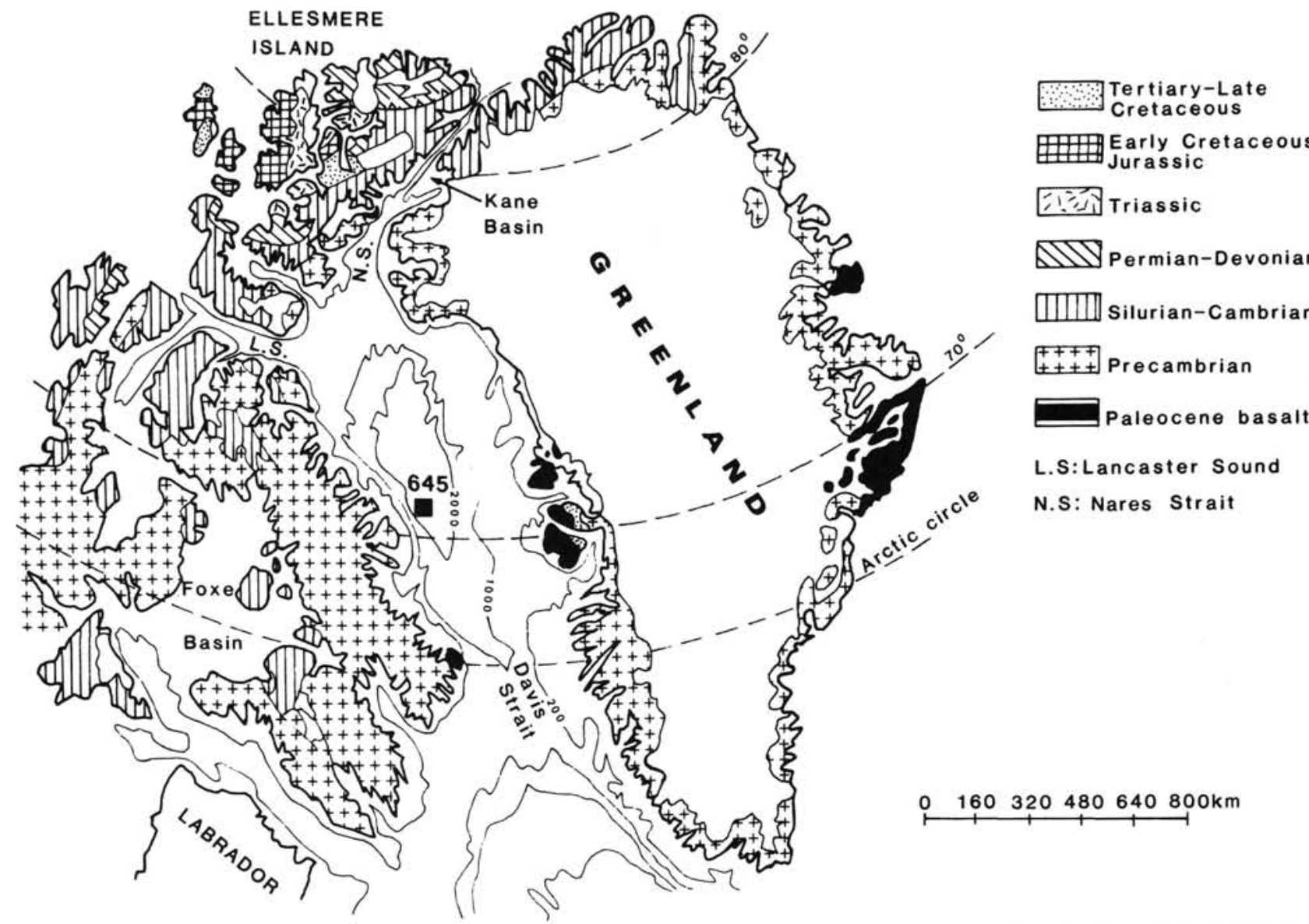

Figure 1. Location of Site 645 and synthetic geological map of Greenland, Baffin, and Ellesmere islands after the Geological World Atlas, Sheet 19 (Choubert and Faure-Muret, 1983).

sieves. The $<63-\mu \mathrm{m}$ fraction was analyzed using a Sedigraph $5000 \mathrm{D}$ particle size analyzer. To preserve the accuracy of data, no corrections were made to account for these distinct techniques. Thus, the coarsest silt-sized fraction $(40-63 \mu \mathrm{m})$ was often under evaluated.

\section{X-Ray Methods}

About 115 samples were subjected to X-ray diffraction analysis on decarbonated particles smaller than $2 \mu \mathrm{m}$. The X-ray diffraction method was conducted as follows.

The samples were first dissociated in water, then decarbonated in $5 \mathrm{~N}$ hydrochloric acid. Excess acid was removed by successive centrifugations. Microhomogenization affects deflocculation. The fraction smaller than $2 \mu \mathrm{m}$ was collected by decantation using Stokes law; then, oriented aggregates were placed on glass slides. The AGGR 60 diffractometer (copper radiation focused by a quartz curved-crystal monochromator) was used to run the $\mathrm{X}$-ray-diffraction scans at $1 \% / \mathrm{min}$. The 1.25 -mm receiving slit allowed better determination of mixed-layer minerals. Three passages were performed: (1) from $1^{\circ}$ to $15^{\circ} 2 \theta$ on natural samples; (2) from $1^{\circ}$ to $7^{\circ}$ or $1^{\circ}$ to $15^{\circ} 2 \theta$ on glycolated samples; and (3) from $1^{\circ}$ to $7^{\circ} 2 \theta$ on samples heated for $2 \mathrm{hr}$ at $490^{\circ} \mathrm{C}$. Semiquantitative evaluations were based on peak heights and areas (Chamley, 1971; Holtzapffel, 1985). The height of illite and chlorite (001) peaks (diagram for glycolated sample) were taken as references.

Here, smectite will represent discrete or pure smectite having less than $15 \%$ illite interlayers. "Smectite" will represent a mixture of pure smectite and irregular mixed-layer illite-smectite having $40 \%$ or more smectite layers. The height of the 17-18-£ peak after glycolation is employed as an indicator of the relative abundance of "smectite" (Reynolds and Hower, 1970). The relative abundance of subregular to regular mixed-layer illite-smectite containing more than $60 \%$ illite-interlayers (IM and IM II of Reynolds and Hower, 1970; IS and IS II of Srodon, 1980 ) is estimated by calculating the area above the background between the $10-\AA$ illite and the $14-\AA$ chlorite peaks of glycolated samples. The abundance of 14-14 mixed-layer clays (chlorite-smectite, vermiculitesmectite, and chlorite-vermiculite) is estimated by using the areas above background between 14 and $17 \AA$ (glycolated samples) and between 10 and $14 \AA$ (heated samples).

The 7- $\AA$ peak gave the total kaolinite plus chlorite; the ratio of these two minerals was deduced from peak height ratios at 3.54 and $3.58 \AA$, respectively; when this ratio is 1 , the amount of chlorite is assumed to be twice that of kaolinite. Data are given in percentages, with a relative error of about $\pm 5 \%$.

For 33 samples (Fig. 3), the proportions (normalized to $100 \%$ ) of pure smectite, random mixed-layer illite-smectite clay, regular mixedlayer illite-smectite clay, and pure illite, and the illite/smectite ratio in mixed-layer illite-smectite clay were estimated by using the $(002)$ illite, $(002 / 003)$ illite-smectite, and (003) smectite reflections on the glycolated sample, in accordance with Srodon's method $(1980,1984)$.

Illite crystallinity (I.A.G. of Kubler, 1968) corresponds to the breadth in ${ }^{\circ} 2 \theta$ of the $10-\AA$ peak at half-height on the glycolated sample diagram. Relative abundance of "smectite" corresponds to the ratio of the 17- and 10- $\AA$ peak heights (Fig. 2), the pure smectite one to the ratio of 5.7-and 5- $\AA$ peak heights (Fig. 3), and the chlorite one to the ratio of 3.54- and 3.58- $\AA$ peak heights (Fig. 2).

To quantify the abundance and crystal perfection of all clay minerals present as well as the presence of amorphous components and organic mineral components, we used the "total clay index" (TCI) of Zimmerman (1984). To estimate TCI, we sum the heights above background of the 17,17 to 14,14 to 10 , and 10 and $7 \AA$ peaks after multiplying by the intensity factors of Holtzapffel (1985). The relative contribution of clayand silt-sized sedimentary components was determined by using the $\mathrm{TCI} /$ quartz ratio calculated from dimensionless values of $\mathrm{TCI}$ and quartz intensity.

Note the presence of zeolites, amphibole, feldspars, and gibbsite in Figure 2. The relative abundance of amphibole and feldspars was calcu- 


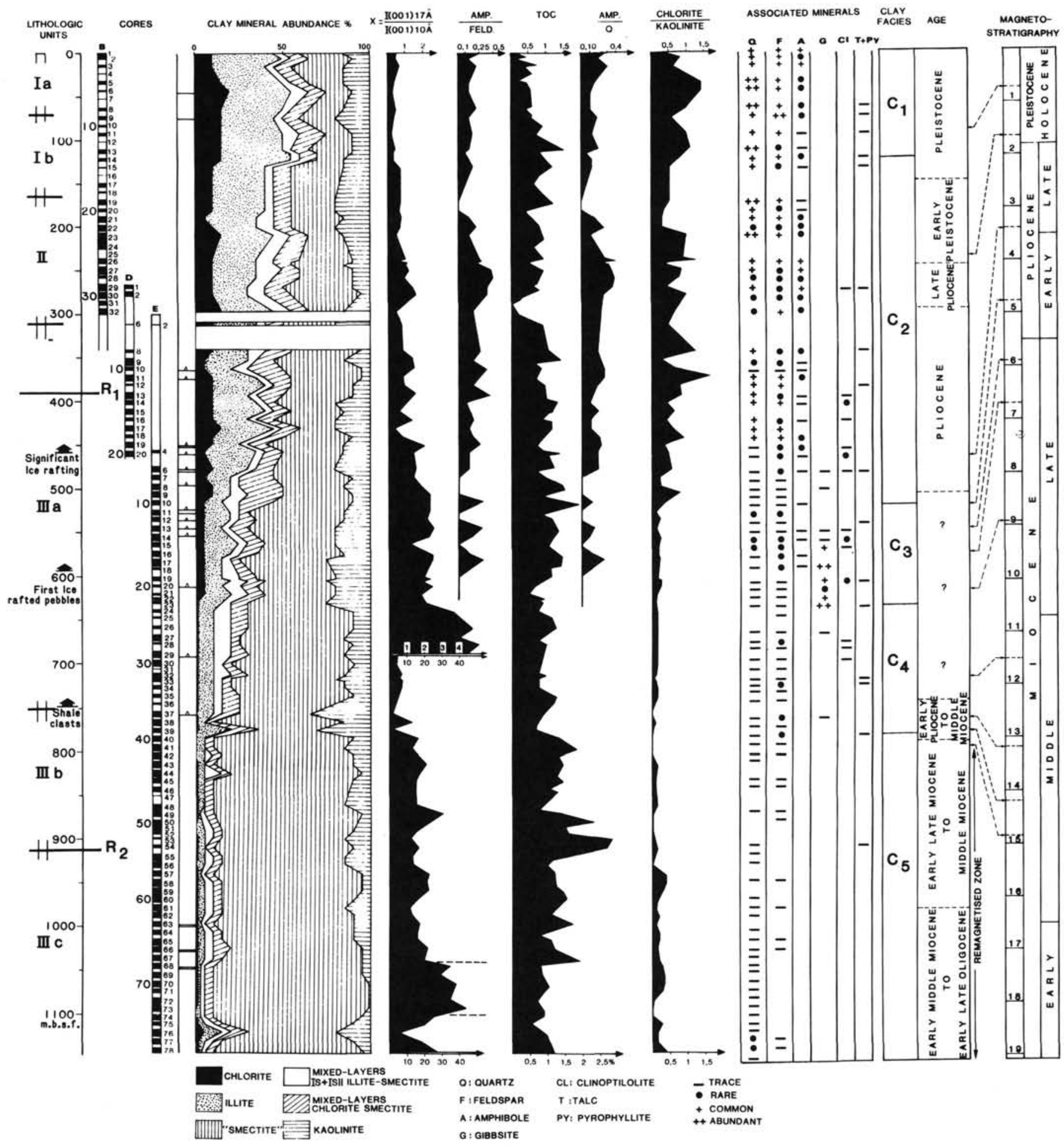

Figure 2. Summary of stratigraphic and mineralogical data for Site 645 .

lated by using peak heights at $8.4 \AA$ (amphibole), $3.24 \AA$ (K feldspar), and $3.18-3.21 \AA$ (plagioclase).

\section{Chemical Analysis of Selected Samples ( $<2-\mu \mathrm{m}$ Fraction)}

Samples were dried at $105^{\circ} \mathrm{C}$, then ground and homogenized. Sample portions $(0.2 \mathrm{~g})$ were subjected to alkaline fusion, then dissolved with $\mathrm{HCl}$ and diluted to $100 \mathrm{~mL}$. This treatment allowed the gravimetric determination of $\mathrm{SiO}_{2}$, colorimetric determination of $\mathrm{P}_{2} \mathrm{O}_{5}$, and spectrophotometric determination of $\mathrm{Fe}_{2} \mathrm{O}_{3}, \mathrm{CaO}, \mathrm{MgO}$, and $\mathrm{Al}_{2} \mathrm{O}_{3}$ (by atomic absorption). Then, 2-g samples were submitted to fluoperchloric treatment, dissolved with $\mathrm{HCl}$, and diluted to $100 \mathrm{~mL}$. That dilution was used for the colorimetric analysis of $\mathrm{TiO}_{2}$, the spectrophotometric analysis of $\mathrm{Na}_{2} \mathrm{O}$ and $\mathrm{K}_{2} \mathrm{O}$ (by emission), and also for traces of manganese and strontium (by atomic absorption).

The apparatus for emission and atomic absorption is a type 503 Perkin-Elmer spectrophotometer, which was used following Pinta's methods (1971): base solution (for major elements) or complex synthetic solution (for trace elements) to which $5 \%$ of lanthane chlorhydric solution was added. 
Table 1. Geochemical data ( $<2 \mu \mathrm{m}$ fractions) from selected samples of Site 645 .

\begin{tabular}{|c|c|c|c|c|c|c|c|c|c|c|c|}
\hline$N^{\circ}$ Sample & $\begin{array}{l}\mathrm{S1O}_{2} \\
\text { wt } \mathrm{x}\end{array}$ & $\begin{array}{l}\mathrm{Al}_{2} \mathrm{O}_{3} \\
\text { wt \& }\end{array}$ & $\begin{array}{l}\mathrm{Fe}_{2} \mathrm{O}_{3} \\
\text { wt \& }\end{array}$ & $\begin{array}{l}\mathrm{CaO} \\
\text { wt \& }\end{array}$ & $\begin{array}{l}\mathrm{MgO} 0 \\
\mathrm{wt} \text { : }\end{array}$ & $\begin{array}{l}\mathrm{Na}_{2} \mathrm{O} \\
\mathrm{wt} \text { \& }\end{array}$ & $\begin{array}{l}\mathrm{K}_{2} \mathrm{O} \\
\mathrm{wt} \text { \% }\end{array}$ & $\begin{array}{l}\mathrm{THO}_{2} \\
\text { wt \$ }\end{array}$ & $\begin{array}{c}\mathrm{Sr} \\
\mathrm{ppm}\end{array}$ & $\begin{array}{l}\mathrm{Mn}_{\mathrm{ppm}} \\
\text {. }\end{array}$ & $\begin{array}{l}\mathrm{Zn} \\
\mathrm{ppm}\end{array}$ \\
\hline $645-E 78-01,114-116$ & 58.1 & 20.26 & 5.94 & 0.35 & 2.82 & n.d. & n.d. & n.d. & 79 & 158 & 79 \\
\hline $645-E 76-03,65-68$ & 53.80 & 24.64 & 4.16 & 0.41 & 2.04 & 0.90 & 2.30 & 1.29 & 132 & 153 & 163 \\
\hline 645-E74-02, 96-99 & 58.10 & 20.14 & 6.49 & 0.61 & 2.76 & 1.40 & 1.28 & 0.94 & 100 & 174 & 210 \\
\hline $645-E 73-03,120-124$ & 59.50 & 20.32 & 5.96 & 0.65 & 2.98 & 0.90 & 1.18 & 1.00 & 110 & 153 & 210 \\
\hline $645-E 70-02,34-38$ & 58.90 & 19.59 & 5.74 & 0.96 & 2.73 & 1.06 & 1.10 & 100 & 116 & 205 & 147 \\
\hline $645-E 67-05,44-48$ & 56.20 & 20.11 & 6.49 & 0.41 & 2.65 & 0.96 & 1.30 & 1.01 & 116 & 231 & 168 \\
\hline $645-E 66-02,101-103$ & 54.70 & 21.59 & 6.44 & 0.47 & 2.74 & 1.34 & 1.64 & 1.16 & 89 & 326 & 105 \\
\hline $645-E 58-04,16-18$ & 56.10 & 18.85 & 7.09 & 0.15 & 2.51 & 1.11 & 1.29 & 0.94 & 95 & 252 & 153 \\
\hline 645-E55-03, 32-35 & 51.40 & 21.94 & 6.38 & 0.82 & 2.46 & 0.90 & 1.56 & 1.00 & 105 & 284 & 79 \\
\hline $645-E 52-01,112-115$ & 52.70 & 21.14 & 8.14 & 0.52 & 2.25 & 0.52 & 1.46 & 1.21 & 132 & 321 & 168 \\
\hline $645-E 49-02,110-115$ & 57.60 & 20.68 & 5.76 & 0.50 & 2.60 & 0.54 & 1.28 & 1.01 & 110 & 184 & 126 \\
\hline $645-E 40-02,81-86$ & 56.10 & 21.67 & 6.22 & 0.46 & 2.69 & 1.16 & 1.74 & 1.25 & 126 & 200 & 137 \\
\hline $645-E 39-02,118-121$ & 47.20 & 24.19 & 8.45 & 0.91 & 2.89 & 0.90 & 2.46 & 1.41 & 153 & 321 & 116 \\
\hline $645-E 38-01,44-47$ & 54.10 & 21.57 & 6.26 & 0.58 & 2.96 & 0.94 & 1.98 & 1.41 & 137 & 226 & 121 \\
\hline $645-E 37-02,84-89$ & 51.60 & 24.86 & 5.97 & 0.51 & 2.21 & 0.73 & 2.05 & 1.04 & 121 & 242 & 768 \\
\hline $645-E 35-03,29-31$ & 56.40 & 18.70 & 6.20 & 0.63 & 2.97 & 0.68 & 1.46 & 1.04 & 95 & 216 & 205 \\
\hline $645-E 32-02,68-71$ & 49.10 & 21.97 & 7.14 & 0.42 & 2.74 & 1.16 & 2.13 & 1.41 & 105 & 242 & 116 \\
\hline $645-E 30-01,132-135$ & 51.10 & 22.11 & 6.22 & 0.45 & 2.97 & 1.04 & 2.04 & 1.29 & 126 & 189 & 153 \\
\hline 645-E29-04, 104-109 & 51.50 & 19.88 & 9.65 & 0.75 & 3.39 & 1.62 & 1.78 & 1.30 & 105 & 331 & 174 \\
\hline 645-E26-02, 62-65 & 53.20 & 21.60 & 6.88 & 0.51 & 3.59 & 0.86 & 2.07 & 1.37 & 126 & 231 & 174 \\
\hline 645-E23-02, 94-96 & 49.70 & 28.04 & 5.17 & 0.28 & 2.12 & 0.70 & 2.28 & 1.16 & 58 & 163 & 121 \\
\hline 645-E21-01, 74-79 & 47.20 & 22.94 & 9.27 & 0.37 & 2.49 & 1.46 & 2.77 & 1.67 & 105 & 252 & 231 \\
\hline $645-\mathrm{E} 20-02,13-18$ & 49.30 & 21.79 & 8.07 & 0.42 & 2.67 & 1.97 & 2.13 & 1.15 & 21 & 231 & 168 \\
\hline 645-E19-01，60-62 & 49.60 & 21.51 & 6.98 & 0.66 & 2.90 & 1.92 & 2.34 & 1.08 & 68 & 237 & 179 \\
\hline $645-E 17-02,124-128$ & 42.60 & 26.56 & 5.01 & 0.36 & 2.15 & 0.56 & 2.26 & 1.00 & 53 & 158 & 137 \\
\hline 645-E15-01, 129-135 & 51.30 & 22.54 & 7.26 & 0.65 & 2.72 & 1.19 & 2.44 & 1.15 & 147 & 268 & 573 \\
\hline 645-E12-02, 90-93 & 50.00 & 19.15 & 7.98 & 0.92 & 3.00 & 1.16 & 1.74 & 0.86 & 58 & 216 & 179 \\
\hline $645-E 6-02,130-135$ & 54.10 & 17.81 & 8.47 & 1.00 & 4.09 & 1.52 & 2.85 & 1.24 & 110 & 395 & 231 \\
\hline $645-020-02,76-80$ & 52.80 & 20.86 & 7.63 & 1.08 & 3.60 & 1.46 & 3.56 & 1.12 & 189 & 400 & 163 \\
\hline $645-D 18-02,75-78$ & 54.00 & 18.21 & 9.02 & 1.61 & 3.76 & 2.44 & 3.31 & 1.20 & 200 & 468 & 110 \\
\hline $645-D 17-04,100-102$ & 54.70 & 19.66 & 7.01 & 0.99 & 3.53 & 1.84 & 3.90 & 1.16 & 147 & 295 & 983 \\
\hline $645-015-04,28-30$ & 54.30 & 19.68 & 7.44 & 1.13 & 3.50 & 1.92 & 3.95 & 1.02 & 195 & 384 & 95 \\
\hline $645-012-01,134-139$ & 60.90 & 18.50 & 7.78 & 1.61 & 4.04 & 1.91 & 3.79 & 1.00 & 168 & 389 & 116 \\
\hline
\end{tabular}


Table 2. Microchemical analyses and structural compositions of minerals from selected samples of Site 645.

\begin{tabular}{|c|c|c|c|c|c|c|c|c|c|c|c|}
\hline & Samples & & $\begin{array}{l}\mathrm{SiO}_{2} \\
\text { wt \% }\end{array}$ & $\begin{array}{l}\mathrm{Al}_{2} \mathrm{O}_{3} \\
\text { wt } \%\end{array}$ & $\begin{array}{l}\mathrm{MgO} \\
w t \%\end{array}$ & $\begin{array}{l}\mathrm{Fe}_{2} \mathrm{O}_{3} \\
\text { wt \% }\end{array}$ & $\begin{array}{l}\mathrm{TiO}_{2} \\
\text { wt \% }\end{array}$ & $\begin{array}{l}\mathrm{K}_{2} \mathrm{O} \\
w t \%\end{array}$ & $\begin{array}{l}\mathrm{Na}_{2} \mathrm{O} \\
w t \%\end{array}$ & $\begin{array}{l}\mathrm{CaO} \\
w t \%\end{array}$ & structural compositions \\
\hline \multirow{15}{*}{ 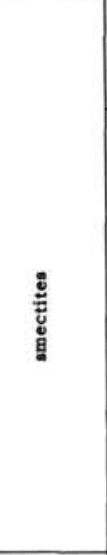 } & \multirow{3}{*}{$\begin{array}{c}645-E 73-03 \\
120-124\end{array}$} & 73-1 & 58.94 & 17.60 & 5.77 & 9.68 & 1.18 & 4.08 & 2.03 & 0.47 & $\left|\mathrm{Si}_{3.70} \mathrm{Al}_{0.30} \mathrm{O}_{10}(\mathrm{OH})_{2}\right|\left(\mathrm{Al}_{1} \mathrm{M}_{\mathrm{g} 0.53} \mathrm{Fe}^{3+}{ }_{0.46} \mathrm{Ti}_{0.06}\right) \mathrm{K}_{0.32} \mathrm{Na}_{0.24} \mathrm{Ca}_{0.03}$ \\
\hline & & $73-2$ & 59.80 & 20.48 & 6.53 & 6.27 & 0.65 & 3.49 & 1.84 & 0.47 & $\left|\mathrm{Si}_{3.69} \mathrm{Al}_{0.31} \mathrm{O}_{10}(\mathrm{OH})_{2}\right|\left(\mathrm{Al}_{1.18} \mathrm{Mg}_{0.60} \mathrm{Fe}^{3+} 0.29 \mathrm{Ti}_{0.03}\right) \mathrm{K}_{0.28} \mathrm{Na}_{0.22} \mathrm{Ca} O .04$ \\
\hline & & $73-3$ & 57.75 & 24.49 & 4.76 & 4.98 & 0.73 & 5.07 & 1.43 & 0.48 & $\left|\mathrm{Si}_{3.57} \mathrm{Al}_{0.43} \mathrm{O}_{10}(\mathrm{OH})_{2}\right|\left(\mathrm{Al}_{1.36} \mathrm{Mg}_{0.44} \mathrm{Fe}^{3+} 0.24 \mathrm{Ti}_{0.02}\right) \mathrm{K}_{0.40} \mathrm{Na}_{0.17} \mathrm{Ca}_{0.03}$ \\
\hline & \multirow{3}{*}{$\begin{array}{c}645-\mathrm{E} 70-02 \\
34-38\end{array}$} & $70-1$ & 60.15 & 30.67 & 3.08 & 5.53 & 0.05 & 0.25 & 0.28 & 0.03 & $\left|\mathrm{Si}_{3.57} \mathrm{Al}_{0.43} \mathrm{O}_{10}(\mathrm{OH})_{2}\right|\left(\mathrm{Al}_{1.69} \mathrm{MgO}_{0.09} \mathrm{Fe}^{3+} 0.25\right) \mathrm{K}_{0.02} \mathrm{Na}_{0.03} \mathrm{Ca}_{0.01} \mathrm{Mg}_{0.18}$ \\
\hline & & $70-2$ & 65.19 & 22.94 & 4.10 & 7.03 & 0.13 & 0.08 & 0.52 & 0.03 & $\left|\mathrm{Si}_{3.86} \mathrm{Al}_{0.14} \mathrm{O}_{10}(\mathrm{OH})_{2}\right|\left(\mathrm{Al}_{1.46} \mathrm{Mg}_{8.32} \mathrm{Fe}^{3+} 0.31 \mathrm{Ti}_{0.01}\right) \mathrm{K}_{0.10} \mathrm{Na}_{0.06} \mathrm{M}_{80.04}$ \\
\hline & & 70-3 & 62.68 & 19.94 & 4.01 & 12.69 & 0.11 & 0.04 & 0.37 & 0.07 & $\left|\mathrm{Si}_{3.80} \mathrm{Al}_{0.20} \mathrm{O}_{10}(\mathrm{OH})_{2}\right|\left(\mathrm{Al}_{1.22} \mathrm{Mg}_{0.28} \mathrm{Fe}^{3+} 0.58 \mathrm{Ti}_{0.01}\right) \mathrm{Na}_{0.04} \mathrm{Mg}_{0.08}$ \\
\hline & \multirow{3}{*}{$\begin{array}{c}645-\mathrm{E} 67-05 \\
44-48\end{array}$} & $67-1$ & 58.95 & 20.58 & 3.03 & 10.20 & 0.83 & 1.91 & 1.08 & 0.53 & $\left|\mathrm{Si}_{3.72} \mathrm{Al}_{0.28} \mathrm{O}_{10}(\mathrm{OH})_{2}\right|\left(\mathrm{Al}_{1.25} \mathrm{M}_{\mathrm{g} 0.28} \mathrm{Fe}^{3+}{ }_{0.48} \mathrm{Ti}_{0.04}\right) \mathrm{K}_{0.16} \mathrm{Na}_{0.13} \mathrm{Ca}_{0.04}$ \\
\hline & & $67-2$ & 61.10 & 21.36 & 2.99 & 7.92 & 0.65 & 1.27 & 0.99 & 0.68 & $\left|\mathrm{Si}_{3.8} \mathrm{Al}_{0.20} \mathrm{O}_{10}(\mathrm{OH})_{2}\right|\left(\mathrm{Al}_{1.37} \mathrm{Mg}_{0.28} \mathrm{Fe}^{3+} 0.37 \mathrm{Ti}_{0.03}\right) \mathrm{K}_{0.10} \mathrm{Na}_{0.12} \mathrm{Ca}_{0.04}$ \\
\hline & & $67-3$ & 63.70 & 22.33 & 3.04 & 5.84 & 0.29 & 0.47 & 0.69 & 0.40 & $\left|\mathrm{Si}_{3.9} \mathrm{Al}_{0.10} \mathrm{O}_{10}(\mathrm{OH})_{2}\right|\left(\mathrm{Al}_{1.51} \mathrm{Mg}_{0.28} \mathrm{Fe}^{3+} 0.26 \mathrm{Ti}_{0.01}\right) \mathrm{K}_{0.04} \mathrm{Na}_{0.09} \mathrm{Ca}_{0.03}$ \\
\hline & \multirow{2}{*}{$\begin{array}{c}645-\mathrm{E} 66-02 \\
101-103\end{array}$} & $66-1$ & 55.10 & 31.98 & 2.99 & 7.28 & 0.05 & 0.38 & 1.81 & 0.45 & $\left|\mathrm{Si}_{3.33} \mathrm{Al}_{0.67} \mathrm{O}_{10}(\mathrm{OH})_{2}\right|\left(\mathrm{Al}_{1.61} \mathrm{Mg}_{\mathrm{g}} .09 \mathrm{Fe}^{3+}{ }_{0.33}\right) \mathrm{K}_{0.03} \mathrm{Na}_{0.22} \mathrm{Ca}_{0.03} \mathrm{Mg}_{\mathrm{g}_{0.18}}$ \\
\hline & & $66-2$ & 60.90 & 23.73 & 4.56 & 7.32 & 0.15 & 0.29 & 2.62 & 0.31 & $\left|\mathrm{Si}_{3.68} \mathrm{Al}_{0.32} \mathrm{O}_{10}(\mathrm{OH})_{2}\right|\left(\mathrm{Al}_{1.37} \mathrm{Mg}_{0.41} \mathrm{Fe}^{3+} 0.33 \mathrm{Ti}_{0.01}\right) \mathrm{K}_{0.02} \mathrm{Na}_{0.30} \mathrm{Ca}_{0.02}$ \\
\hline & \multirow{4}{*}{$\begin{array}{c}\text { 645-E23-02 } \\
94-96\end{array}$} & 23-1 & 56.79 & 32.88 & 2.50 & 5.24 & 0.07 & 0.71 & 1.56 & 0.17 & $\left|\mathrm{Si}_{3.40} \mathrm{Al}_{0.60} \mathrm{O}_{10}(\mathrm{OH})_{2}\right|\left(\mathrm{Al}_{1.72} \mathrm{Mg}_{0.06} \mathrm{Fe}^{3+} 0.24\right) \mathrm{K}_{0.05} \mathrm{Na}_{0.19} \mathrm{Ca}_{0.01} \mathrm{Mg}_{0.17}$ \\
\hline & & $23-2$ & 57.94 & 29.20 & 3.22 & 6.57 & 0.08 & 0.65 & 2.07 & 0.21 & $\left|\mathrm{Si}_{3.48} \mathrm{Al}_{0.51} \mathrm{O}_{10}(\mathrm{OH})_{2}\right|\left(\mathrm{Al}_{1.56} \mathrm{M}_{\mathrm{B} 0.19} \mathrm{Fe}^{3+}{ }_{0.30} \mathrm{Ti}_{0.01}\right) \mathrm{K}_{0.05} \mathrm{Na}_{0.24} \mathrm{Ca}_{0.01} \mathrm{M}_{\mathrm{B} 0.10}$ \\
\hline & & $23-3$ & 52.37 & 25.60 & 4.58 & 13.63 & 0.15 & 0.46 & 2.80 & 0.36 & $\left|\mathrm{Si}_{3.28} \mathrm{Al}_{0.72} \mathrm{O}_{10}(\mathrm{OH})_{2}\right|\left(\mathrm{Al}_{1.17} \mathrm{Mg}_{\mathrm{g} 0.26} \mathrm{Fe}^{3+} 0.64 \mathrm{Ti}_{0.01}\right) \mathrm{K}_{0.03} \mathrm{Na}_{0.34} \mathrm{Ca}_{0.02} \mathrm{Mg}_{\mathrm{g} 0.16}$ \\
\hline & & $23-4$ & 49.68 & 22.20 & 5.74 & 18.40 & 0.11 & 0.48 & 2.98 & 0.33 & $\left|\mathrm{Si}_{3.18} \mathrm{Al}_{0.82} \mathrm{O}_{10}(\mathrm{OH})_{2}\right|\left(\mathrm{Al}_{086} \mathrm{Mg}_{8.35} \mathrm{Fe}^{3+} 0.89 \mathrm{Ti}_{0.01}\right) \mathrm{K}_{0.04} \mathrm{Na}_{0.37} \mathrm{Ca}_{0.02} \mathrm{MgO}_{8.19}$ \\
\hline Chlorite & $645-E 66-02$ & $101-103$ & 43.63 & 19.06 & 2.53 & 31.23 & 0.34 & 0.23 & 2.64 & 0.34 & $\left|\mathrm{Si}_{3.21} \mathrm{Al}_{0.79} \mathrm{O}_{10}(\mathrm{OH})_{2}\right|\left(\mathrm{Al}_{0.32} \mathrm{Fe}^{3+}{ }_{1.6} \mathrm{Ti}_{0.01}\right) \mathrm{Na}_{0.14} \mathrm{Ca}_{0.03}\left(\mathrm{Mg}_{1.49} \mathrm{Al}_{1.27}\right)(\mathrm{OH})_{6}$ \\
\hline \multirow{2}{*}{ Kaolinite } & 645-E66-02 & $109-103$ & 53.57 & 40.72 & 1.60 & 2.40 & 0.04 & 0.28 & 1.10 & 0.23 & $\mathrm{Si}_{2}\left(\mathrm{Al}_{1.81} \mathrm{Fe}^{3+} 0.07 \mathrm{Mg}_{0.09} \mathrm{Ti}_{0.01}\right) \mathrm{O}_{5}(\mathrm{OH})_{4} \mathrm{~K}_{0.02} \mathrm{~N}_{0.08} \mathrm{Ca}_{0.02}$ \\
\hline & 645-E23-02 & $94-96$ & 52.52 & 40.29 & 1.37 & 3.30 & 0.03 & 0.51 & 1.68 & 0.26 & $\left(\mathrm{Si}_{1.99} \mathrm{Al}_{0.01}\right)\left(\mathrm{Al}_{1.80} \mathrm{Mg}_{0.07} \mathrm{Fe}^{3+} 0.10\right) \mathrm{O}_{5}(\mathrm{OH})_{4} \mathrm{~K}_{0.03} \mathrm{Na}_{0.12} \mathrm{Ca}_{0.01}$ \\
\hline illite & 645-E67-05 & 44-48 & 52.04 & 25.89 & 3.32 & 10.42 & 0.84 & 5.62 & 1.01 & 0.82 & \\
\hline
\end{tabular}

\section{Semiquantitative Chemical Microanalysis of Clay Minerals}

Microchemical analysis of the clay fraction $(<2 \mu \mathrm{m})$ of five samples was conducted using a Camebax electronic microprobe apparatus that consisted of three spectrometers working simultaneously and automatically. The following elements were measured semiquantitatively: sodium, silicon, aluminum (reference to albite), iron, calcium (reference to andratite), potassium (reference to orthoclase), magnesium, titanium, manganese, chromium, nickel, and zinc (reference to different pure substances). The results are expressed in mass concentration of oxides and reported in weight percentages after correcting for the absorption and fluorescence effects (Debrabant et al., 1985).

\section{Geochemistry of Total Rocks}

Major elements $\left(\mathrm{SiO}_{2}, \mathrm{Al}_{2} \mathrm{O}_{3}, \mathrm{Fe}_{2} \mathrm{O}_{3}, \mathrm{MnO}, \mathrm{MgO}, \mathrm{CaO}, \mathrm{K}_{2} \mathrm{O}\right.$, $\mathrm{Na}_{2} \mathrm{O}, \mathrm{TiO}_{2}$, and $\mathrm{P}_{2} \mathrm{O}_{5}$ ) analyses of 10 samples were performed using emission spectrometry (ARL quantometer used in the Centre de Recherches Pétrographiques et Géochimiques de Nancy, France). The same samples were analyzed for trace elements (barium, cobalt, chromium, copper, nickel, strontium, vanadium, and rubidium) by semiquantitative spectrography.

\section{GRAIN-SIZE STUDY}

\section{Downhole Lithological Evolution}

In the lithologic diagram (Fig. 3), we show the percentage of particles that are coarser than $250 \mu \mathrm{m}$, of fine sand (250-63 $\mu \mathrm{m})$, of silt $(63-1.6 \mu \mathrm{m})$, and of the clay fraction $(<1.6 \mu \mathrm{m})$. According to the classification scheme used in core descriptions during Leg 105, the sediments of Site 645 can be described as mainly muds because the clay fraction is always higher than $10 \%$ and the sand fraction commonly exceeds $10 \%$. However, the main textural changes that were used to define lithologic units on board ship were observed again, and additional limits may be distinguished.

Lithologic Unit $\mathrm{I}$ is characterized by a high clay content as well as a high proportion of particles coarser than $250 \mu \mathrm{m}$. The latter increases from the bottom to the top of Unit 1 (Fig. 4).

Lithologic Unit II does not exhibit a general trend but a rapid succession of clayey silt, muddy silts, and muddy sands.
The sandy silt interval described in Cores $105-645 \mathrm{D}-2 \mathrm{R}$ and $105-$ 645B-30X was recovered at 275-280 mbsf. No major change occurs on both sides of the poor recovery zone where the limit of Units II and III were placed.

Subunit IIIA can be subdivided into three sequences defined by an increase in the clay fraction at 600 and $460 \mathrm{mbsf}$. The sediments from the lowest sequence (735-600 mbsf) are commonly characterized by a high percentage of fine sands and a very low clay content. Therefore, the term "sandy silt" and "silty sand" is more appropriate to describe such sediments than the term "mud." The coarse fraction is insignificant (Fig. 4).

The overlying sequence (600-460 mbsf) starts with a sharp decrease of the fine sand fraction, an increase of clay content, and the appearance of a low but significant percentage of coarse particles. This change takes place in Core 105-645E-19R, where the lowest inferred ice-rafted pebble was observed. A similar change occurs at $\mathbf{4 6 0} \mathrm{mbsf}$ : the clay content increases again as the coarse particle content increases. Between these two limits, silty muds, defined by a relatively high fine sand percentage and low clay content, overlay finer-grained clayed silts. Moreover, as shown by the sharp peak at 556 mbsf (section 645E-14R-3), few coarser-grained beds occur in this sequence. These correspond to the normally graded muddy sand intervals that characterize Subunit IIIA.

The upper sequence (460-350) starts with clayey silts. Upward, the medium-to-coarse sand fraction increases independently of the fine sand fraction and defines silty muds. It reaches a maximum at $400 \mathrm{mbsf}$, and afterward rapidly decreases while the clay content also decreases until it reaches a minimum at 362 mbsf. The first graded units occur at this depth.

Subunits IIIB and IIIC are characterized by the variation of the fine sand content, which, except the bottommost part of the hole, decreases upward from about $40 \%$ to less than $5 \%$. The higher sand percentage at 1000 mbsf corresponds to a distinctly laminated muddy sand. Surprisingly, the clay content crudely follows the same trend: it is slightly higher when the percentage of sand increases. These variations depict a fining-upward sequence and confirm that Subunit IIIB is finer grained than Sub- 
Table 3. Geochemical analyses of total rocks from selected samples of Site 645 .

\begin{tabular}{|c|c|c|c|c|c|c|c|c|c|c|c|c|c|c|c|c|c|c|}
\hline Samples & $\begin{array}{l}\mathrm{SiO}_{2} \\
\text { wt }\end{array}$ & $\begin{array}{l}\mathrm{Al}_{2} \mathrm{O}_{3} \\
\text { wt } x\end{array}$ & $\begin{array}{c}\mathrm{Fe}_{2} \mathrm{O}_{3} \\
\text { wt : }\end{array}$ & $\begin{array}{l}\text { Mno } \\
\text { wt } \Sigma\end{array}$ & $\begin{array}{l}\mathrm{MgO} \\
\mathrm{wt} \text { \& }\end{array}$ & $\begin{array}{l}\mathrm{CaO} \\
\text { wt } \mathrm{I}\end{array}$ & $\begin{array}{l}\mathrm{Na}_{2} \mathrm{O} \\
\mathrm{wt} \text { : }\end{array}$ & $\begin{array}{l}\mathrm{K}_{2} \mathrm{O} \\
\mathrm{wt}=\end{array}$ & $\begin{array}{l}\mathrm{T}^{1 \mathrm{O}_{2}} \\
\mathrm{wt} \text { \$ }\end{array}$ & $\begin{array}{l}\mathrm{P}_{2} \mathrm{O}_{5} \\
\mathrm{wt} \text { : }\end{array}$ & $\begin{array}{c}\text { Ba } \\
\text { ppm }\end{array}$ & $\begin{array}{l}\text { Ca } \\
\text { ppm }\end{array}$ & $\begin{array}{c}\mathrm{Cr} \\
\mathrm{ppm}\end{array}$ & $\begin{array}{l}\mathrm{Cu} \\
\mathrm{ppm}\end{array}$ & $\begin{array}{c}\mathrm{Ni} \\
\mathrm{ppm}\end{array}$ & $\begin{array}{l}\mathrm{Sr} \\
\mathrm{ppm}\end{array}$ & $\underset{p p m}{v}$ & $\begin{array}{c}\mathrm{Rb} \\
\mathrm{ppm}\end{array}$ \\
\hline $645-E 75-03,67-70$ & 59.35 & 15.10 & 6.39 & 0.05 & 2.14 & 1.52 & 2.27 & 3.33 & 1.01 & 0.11 & 641 & 25 & 133 & 28 & 78 & 198 & 169 & 111 \\
\hline 645-E72-02, 66-69, & 64.59 & 13.26 & 4.35 & 0.04 & 1.55 & 0.92 & 2.21 & 2.86 & 0.97 & 0.07 & 686 & 24 & 124 & 26 & 74 & 188 & 136 & 86 \\
\hline 645-E69-02, 104-109 & 59.71 & 13.87 & 6.22 & 0.04 & 1.53 & 0.80 & 2.04 & 2.63 & 1.04 & 0.13 & 571 & 33 & 141 & 30 & 102 & 171 & 159 & 83 \\
\hline $645-E 68-03,60-64$ & 59.81 & 13.56 & 5.73 & 0.05 & 1.78 & 1.05 & 2.07 & 2.82 & 1.06 & 0.64 & 664 & 23 & 135 & 25 & 86 & 194 & 150 & 94 \\
\hline $645-E 43-03,51-54$ & 60.26 & 14.96 & 5.61 & 0.04 & 1.56 & 0.77 & 2.00 & 2.46 & 1.22 & 0.15 & 522 & 33 & 149 & 40 & 104 & 174 & 200 & 76 \\
\hline 645-E41-05, 81-84 & 56.78 & 16.04 & 6.04 & 0.04 & 2.13 & 0.72 & 1.93 & 2.39 & 1.20 & 0.14 & 478 & 28 & 148 & 45 & 97 & 164 & 209 & 72 \\
\hline 645-E34-02, $108-110$ & 60.47 & 14.13 & 5.77 & 0.05 & 1.64 & 1.06 & 2.03 & 2.59 & 1.07 & 0.11 & 537 & 31 & 138 & 37 & 90 & 182 & 181 & 71 \\
\hline $645-E 27-03,60-65$ & 64.33 & 12.39 & 4.65 & 0.05 & 1.87 & 1.30 & 2.15 & 2.78 & 1.03 & 0.40 & 602 & 26 & 123 & 25 & 66 & 200 & 149 & 77 \\
\hline 645-E24-02, 65-70 & 65.92 & 12.68 & 4.8 & 0.05 & 1.61 & 1.16 & 2.16 & 2.70 & 1.03 & 0.12 & 587 & 33 & 145 & 32 & 76 & 188 & 159 & 73 \\
\hline 645-E13-02, 88-93 & 56.29 & 15.61 & 5.16 & 0.05 & 2.25 & 1.00 & 1.48 & 2.88 & 0.99 & 0.10 & 411 & 25 & 117 & 36 & 71 & 132 & 197 & 103 \\
\hline
\end{tabular}

unit IIIC, but that it does not show a significant change around 920 mbsf, where the $R_{2}$ reflector and the boundary of lithologic Subunits IIIB and IIIC was placed.

\section{Comments}

The downhole evolution of texture described above underlines an important boundary at $600 \mathrm{mbsf}$. Above $600 \mathrm{mbsf}$, sediments commonly contain a high clay content and also contain a significant proportion of coarse particles that globally increase upward (fig. 4). More often, this coarse fraction ranges from medium sand to granule-sized particles. Below $600 \mathrm{mbsf}$, the coarse fraction is insignificant (less than $2 \%$ ) in respect to the fine sand fraction (Fig. 4) and the clay content is low (Fig. 5). This boundary at $600 \mathrm{mbsf}$ closely corresponds to the lowest occurrence in a clayey silt of a pebble that is difficult to interpret as having any origin other than ice rafting.

The appearance of coarse particles concomitant to an increase of clay content at this depth is in agreement with ice rafting as a transport process, which leads (Fig. 6) to poorly sorted sediments (Andrews, 1985; Fillon et al., 1981). Therefore, variations of the coarse fraction are related to fluctuations of supply from melting icebergs. If evidence of ice rafting occurs at 600 mbsf, the low coarse particle content up to 460 mbsf (Fig. 4) indicates that ice rafting may not have been the dominant transporting agent. Evidence of ice rafting increases uphole and reaches a maximum at $400 \mathrm{mbsf}$, near the depth of the $R_{1}$ reflector (Srivastava, Arthur, et al., 1987), and then becomes weaker at the top of Unit III. Unit II is characterized by important fluctuations in ice-rafted detritus. Ice rafting finally became progressively dominant in Unit I.

Below $600 \mathrm{mbsf}$, the coarse fraction of the muddy sands and sandy silts is composed of only fine sand-sized particles. The coarser fifth percentiles rarely exceed $160 \mu \mathrm{m}$; however, their modal sizes fall into the fine sand class, and they show a pronounced fine-grained tail that gives positive assymetrical frequency curves (Fig. 6). Such characteristics indicate a transporting agent unable to carry medium sand but able to sort fine sand by removing silts and clay.

Sediments of Unit III are also characterized by laminations that become more pervasive and distinct downhole (Fig. 3). Laminations are not apparent in the clayey silts between 730 and $800 \mathrm{mbsf}$, which are more strongly bioturbated. Conversely, the coarser-grained sediments of the bottom part of the hole are less ioturbated and show thinly interbedded muddy sand and silty sand horizontal laminae that are indicative of current action (see Cremer, this volume). Contacts between intervals of distinct lithology are commonly transitional and are either coarsening or fining upward. Finally, we were unable to observe in Unit III any sharp-based grading from sand to silty clay sequences, which would indicate turbidites. Conversely, the relationship between the occurrence of the laminations and grain size and the presence of a pervasive bioturbation (more marked in the finergrained sediments) makes these sediments very similar to the contourites described by Gonthier et al. (1984). This interpretation of a pronounced influence of deep current during deposition of Unit II is consistent with the current drift-building deduced from seismic interpretation (see Arthur et al., this volume). Therefore, the prevalent fining-upward sequence from Subunit IIIC to Subunit IIIB is related to a weakening of bottom currents. From seismic evidence, however, the $\mathbf{R}_{2}$ reflector at the boundary of these subunits was interpreted as the result of the onset of vigorous currents; it is marked only by a slight textural change. Nevertheless, it corresponds to the bottom of a more homogeneous sequence, finely laminated throughout, in contrast to the underlying succession of silty muds and muddy sands, which are either homogeneous or distinctly laminated. Consequently, this change may be related to a transition from highly variable to weaker but constant influence of bottom currents. This also agrees with an increase in the sedimentation rate at this depth caused by a decrease of winnowing and an increase in net deposition.

Sediments of the bottom part of Subunit IIIA (600-730 mbsf) exhibit grain-size characteristics similar to those already described for Subunit IIIC (Fig. 6). Moreover, identical sedimentary structures can be found (homogeneous to distinctly laminated intervals, fining- and coarsening-upward cycles, pervasive bioturbation). Thus, this interval also was interpreted as being deposited under a strong influence of bottom currents. The pronounced reflector at 724 mbsf marks this sharp increase of current velocity.

Above $600 \mathrm{mbsf}$, several intervals show a low proportion of clay and coarse particles and relatively high fine sand content that precludes a direct deposition from melting icebergs. In these intervals (360-380 mbsf and $450-560 \mathrm{mbsf}$ ), normally graded sequences were described and tentatively interpreted as turbidites. The study of one of these beds reveals effectively an upward grading, but the basal sample is surprisingly similar to the sandy contourites below $600 \mathrm{mbsf}$. Moreover, grain-size 


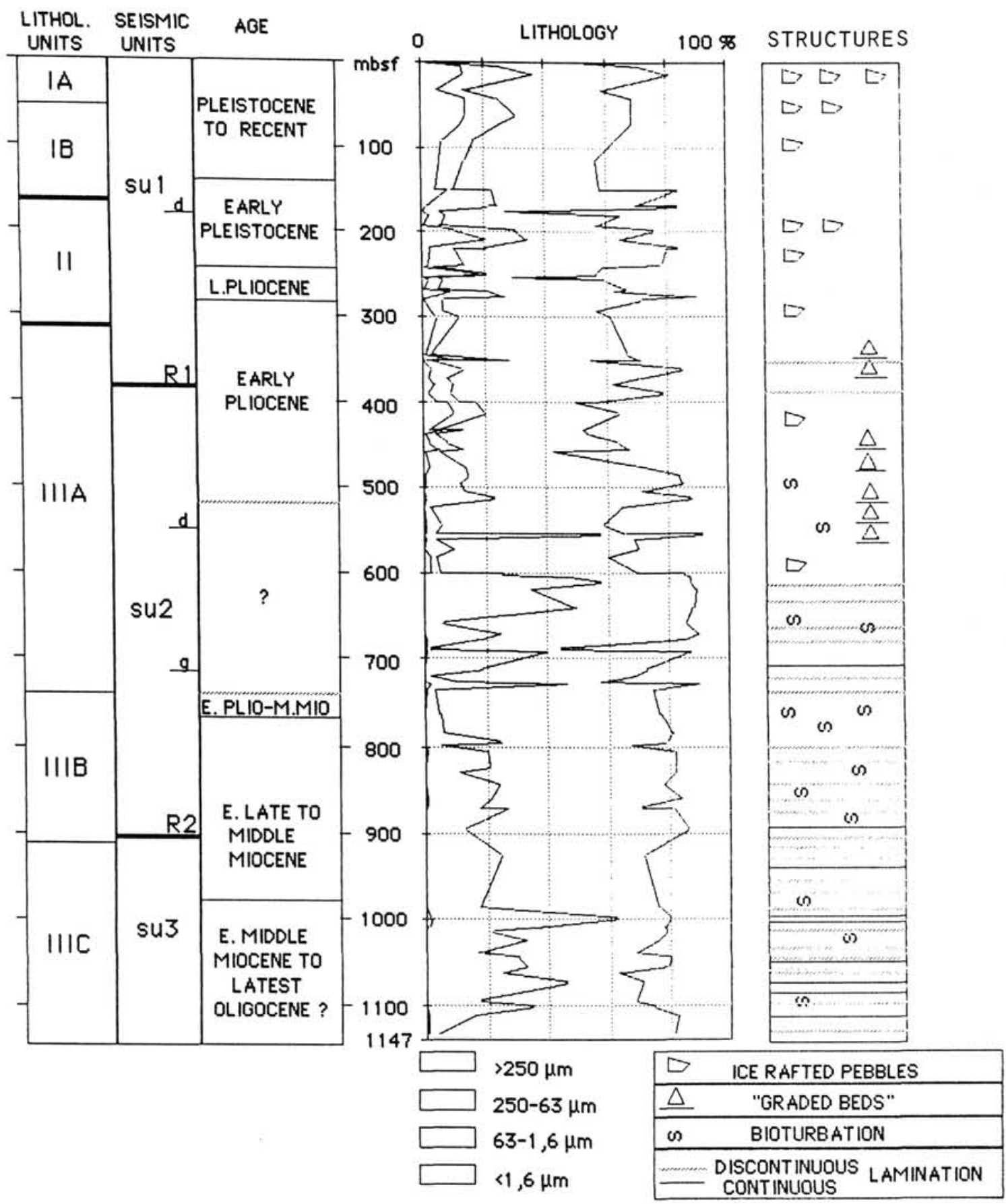

Figure 3. Lithologic units, seismic units, and ages at Site 645; grain-size variations and schematic diagram of sedimentary structures are also shown.

analysis from other "graded beds" (Hiscott et al., this volume) did not exhibit grading but a higher percentage of clay size particles at their base. We observed in Subunits IIIB and IIIC that clay content was slightly higher in muddy sands than in silty muds. Finally, there is seismic evidence that bottom currents were still active upslope during deposition of sediments for Subunit IIIA through Unit II (Arthur et al., this volume). The presence of granules, concentrated at the bottom or scattered throughout the graded muddy sand units, implies that if bottom currents were responsible for deposition of these sediments, then they would have had to be very strong. Nevertheless, these graded beds appear after the initiation of ice rafting and, although turbidity current origin cannot be definitively ruled out, the coarse particles may have been supplied by ice rafting and winnowed after the deposition of finer-sized sediments by bottom currents. The uppermost sample of asymmetrically sorted sandy silt (Fig. 5) was recovered from Core 105-645D-2R at $276 \mathrm{mbsf}$, again in a sequence starting with a short coarsening-upward, followed by a long fining-upward. According to the above hypothesis, the sandier interval around 270 mbsf may be interpreted as the last 

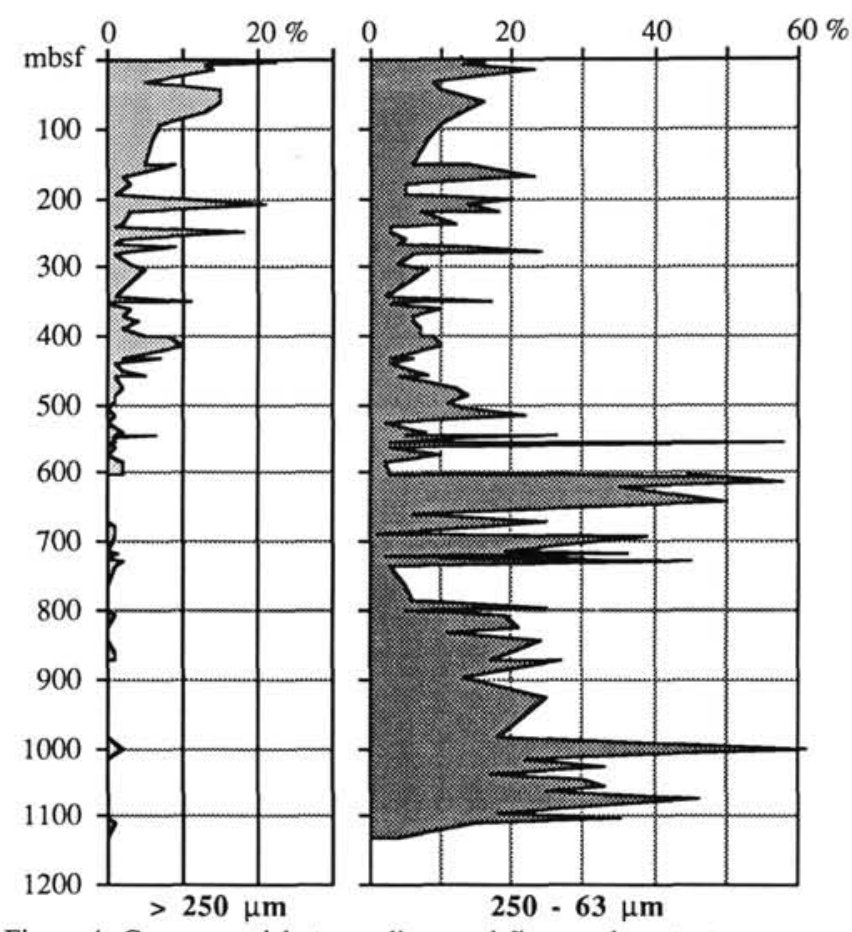

Figure 4. Coarse particle to medium and fine sand contents.

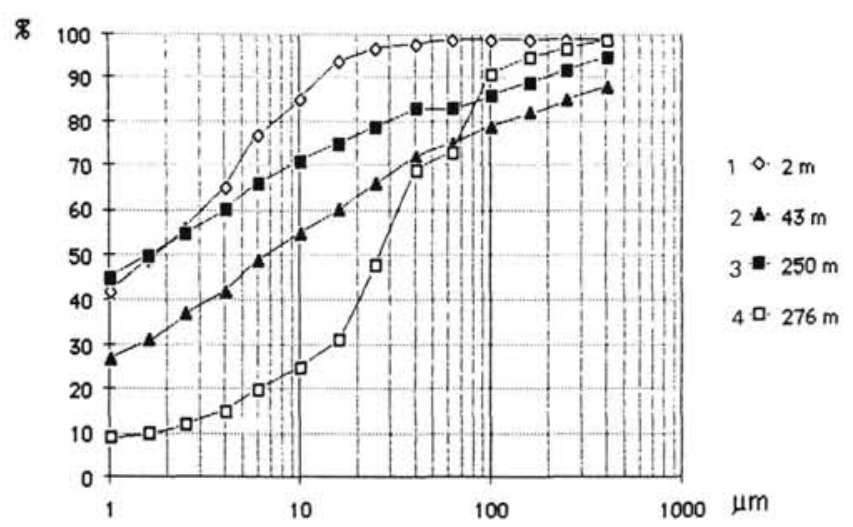

Figure 5. Example of grain-size distribution from lithologic Units I and II; 1) silty clay related to hemipelagic decantation; 2 and 3) clayey mud characteristic of ice-rafted detritus; 4) sandy silt winnowed of finegrained sediments.

notable influence of bottom currents before the dominant icerafting supply that characterizes the upper part of the section.

\section{CLAY MINERALS}

Starting at the bottom of the Site 645 section (Fig. 2), the clay mineral assemblage evolution is dominated by the antithetic relationship between "smectite" and illite relative abundances. "Smectite" is particularly abundant in the lowest part of the section. Illite forms up to $40 \%$ of the clay mineral assemblage in the uppermost part of the same section. Above $620 \mathrm{mbsf}$, the chlorite content appears to vary parallel with the illite content. Kaolinite abundance is low throughout the section but shows some abrupt increases. Mixed-layer clays are always minor. The clay mineral variability along with the TCI ("total clay index," see "Methods" section for explanation) allows the section to be divided into facies that do not always correspond to the litho-

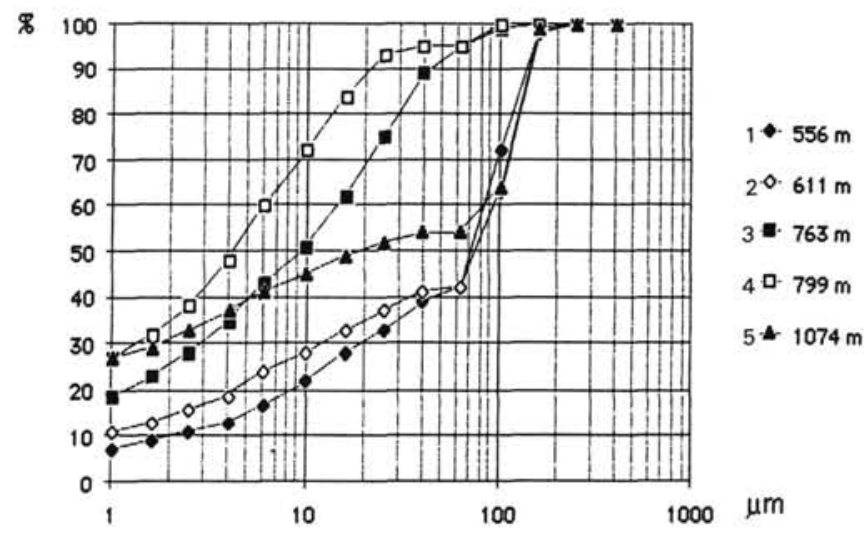

Figure 6. Examples of grain-size distribution from lithological Unit III; 1 and 2) sandy silt having a long fine tail; 3 ) clayey silt moderately well sorted; 4) finer-grained clayey silt; 5) muddy sand with a more important fine tail.

logic units. Five facies were identified and considered in stratigraphic order.

\section{Facies 5}

Facies 5 composes the lowest part of the section (Cores 105$645 \mathrm{E}-78 \mathrm{R}$ to $105-645 \mathrm{E}-40 \mathrm{R}, 782$ to $1147 \mathrm{mbsf}$ ). The clay mineralogy shows (except Core 105-645E-76) homogeneous assemblages having a high TCI/quartz ratio, high "smectite"/illite ratio (Fig. 7), and low chlorite/kaolinite ratio (Fig. 2). These characteristics suggest that these assemblages are dominated by "smectite" ( $70 \%-90 \%, 78 \%$ on average), with little amounts of kaolinite (up to $20 \%$ ) and illite (up to $10 \%$ ), and chlorite is always a minor component compared to kaolinite and illite.

The "smectite"/illite ratio is high as a result of the abundance of pure smectite in the fully expandable clay $(30 \%-70 \%$, $48 \%$ on average). The position of the $(003)$ and $(005)$ reflections of smectite were used to determine the thickness of the two-layer ethylene glycol complex of the dominant dioctahedral smectites (Srodon, 1980). The studied smectites show a 17.2 $\AA$ thickness for the clay-ethylene glycol complex (Fig. 8).

This thickness and the reflections between 15.7 to $17.7^{\circ} 2 \theta$ for the glycolated samples (Srodon, 1980) were used to estimate the smectite/illite ratio of the mixed-layer structure and the relative abundances of illite, mixed-layer illite/smectite, and smectite (Fig. 7).

A very strong reflection at $62^{\circ} 2 \theta(1.495 \AA)$ (Fig. 7) indicates the general predominance of dioctahedral smectite (montmorillonite-beidellite). The reflection between 60 and $60.35^{\circ} 2 \theta(1.532$ to $1.541 \AA$ ) cannot possibly be explained by the $(060)$ reflection of chlorite or the (211) reflection of quartz, which are always very minor phases. This reflection suggests that a trioctahedral smectite may contribute slightly to the fully expandable phase.

Generally, illite is of good X-ray crystallinity $\left(0.2^{\circ}\right.$ to $0.5^{\circ}$ $2 \theta$ ). The ratio of the $002 / 001$ illite reflections varies between 0.3 to 0.7 . The lowest values for well-crystallized illite suggest a relativly high iron content (Brindley and Brown, 1980) or a small glauconitic contribution.

The TCI of facies 5 is high as a result of the relative abundance of the clay component. A high TCI/quartz ratio indicates the general predominance of clay over quartz silt. The clay assemblage of a sample from Core 105-645E-76R shows a lower $\mathrm{TCI}$ and TCI/quartz ratio and an important decrease in relative abundance of smectite. Kaolinite abundance is $20 \%$, illite is $10 \%$, and chlorite is $5 \%$. 


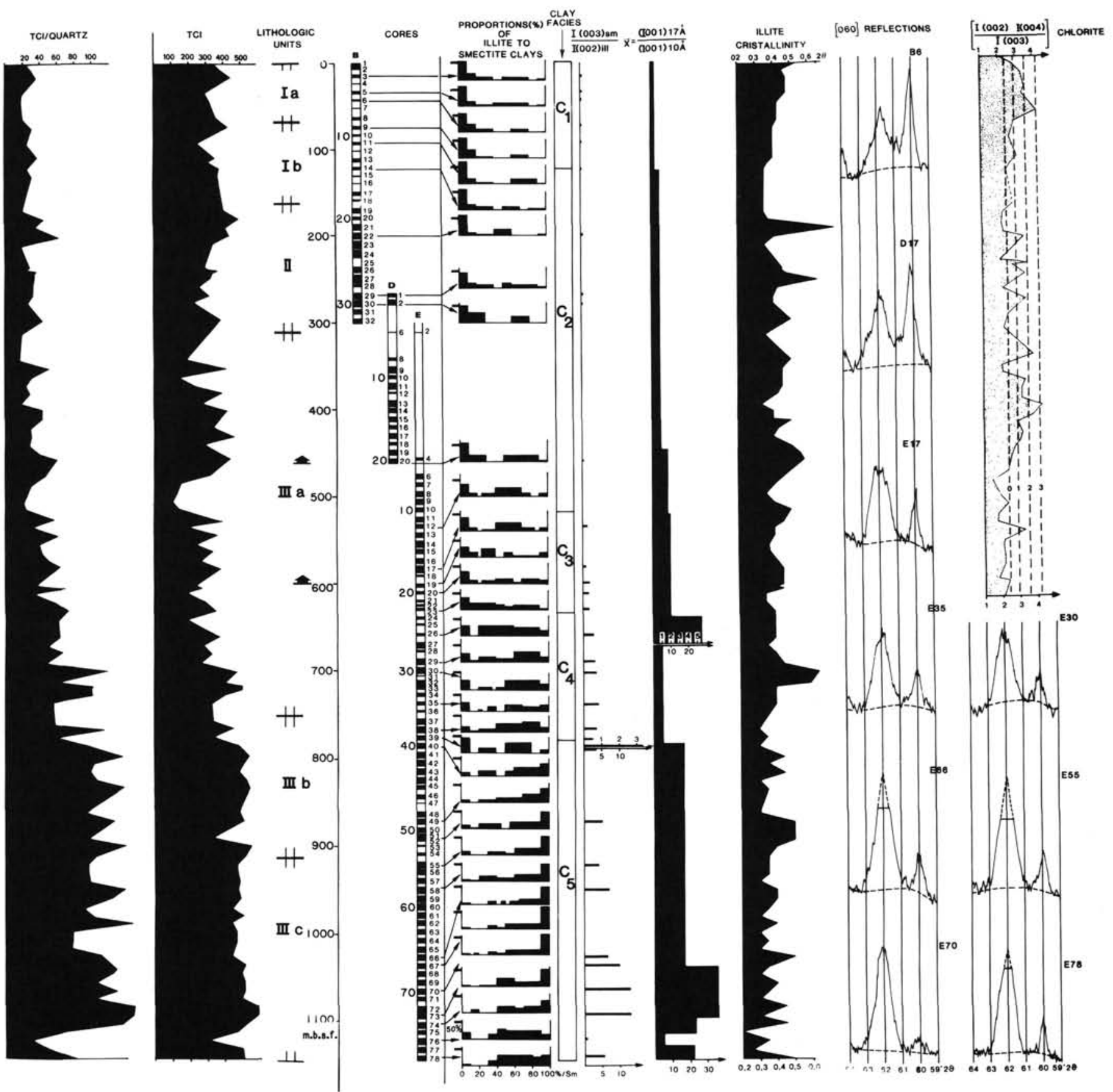

Figure 7. Clay mineralogical data for Site 645.

\section{Facies 4}

Overlying facies 5 , facies 4 comprises middle Miocene to middle to early Pliocene(?) sediments of the lowest part of lithologic Subunit IIIA (Cores 105-645E-39R to $-24 \mathrm{R}, 630$ to 782 mbsf).

The base of facies 4 is marked (Figs. 2 and 7) by abrupt decreases of the TCI/quartz, "smectite"/illite, smectite/illite ratios, and of the total organic carbon contents (Fig. 2). The decreases in the "smectite"/illite and smectite/illite ratios suggest important quantitative and qualitative changes in the illite/ smectite clay assemblages. The fully expandable clay is less abundant $(70 \%-35 \%, 59 \%$ on average) and is dominated by mixed-layer illite/smectite clay. The relative abundance of smectite begins at lower than $20 \%(5 \%-15 \%, 12 \%$ on average). The reflections between $59^{\circ}$ and $62^{\circ} 2 \theta$ (060 reflection) indicate the dominance of dioctahedral smectite with a relative increase of trioctahedral smectite abundance, while chlorite and quartz remain very minor phases. Illite is of good-to-poor crystallinity $\left(0.3^{\circ}\right.$ to $\left.0.65^{\circ} 2 \theta\right)$. The ratio between the $002 / 001$ illite reflections varies between 0.34 to 0.41 .

At the base of facies 4, kaolinite abundance abruptly increases up to $30 \%-35 \%$ (Cores $105-645 \mathrm{E}-39 \mathrm{R}$ and $-37 \mathrm{R}$ ) and decreases upward to $10 \%-15 \%$. The decrease in the TCI/quartz ratio reflects the quantitative changes in clays rather than the small amounts of quartz silt.

\section{Facies 3}

Facies 3 (Cores 105-645E-11R to $-22 \mathrm{R}, 513$ to $630 \mathrm{mbsf}$ ) consists of a late Miocene to early Pliocene(?) sequence exhibiting the first ice-rafted granitic pebble (Sample 105-645E-19R-3, 90- 


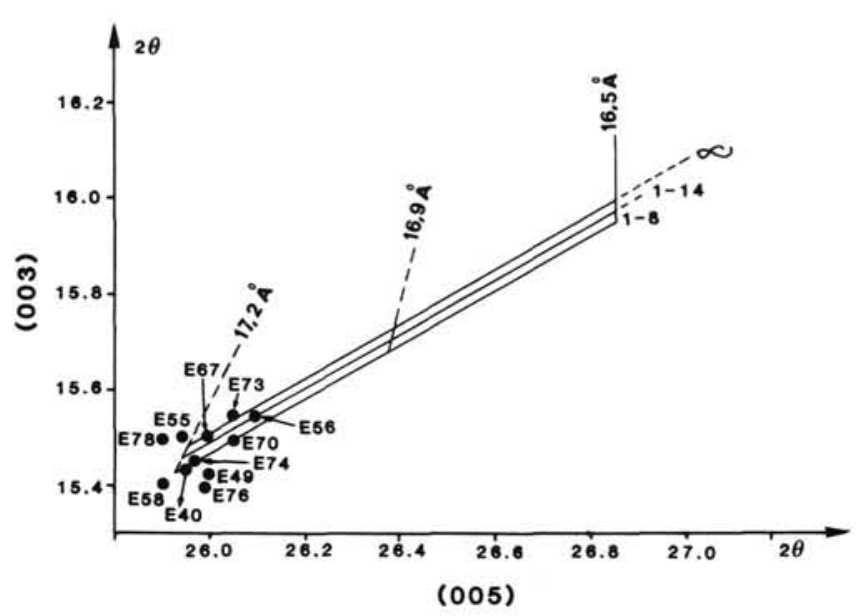

Figure 8. Plot of ${ }^{\circ} 2 \theta(003)$ vs. ${ }^{\circ} 2 \theta(005)$ for variable ethylene glycolsmectite thicknesses at Site 645 . The three lines represent an infinite number, 1-14, and 1-8 layers/domain (Srodon, 1980).

$100 \mathrm{~cm}$, at $604 \mathrm{mbsf}$ ) and the first occurrence of amphibole in the silt fraction. The base of facies 3 is marked (Figs. 2 and 7) by an abrupt decrease in the "smectite"/illite ratio, a slight decrease in the smectite/illite ratio, and an abrupt increase of relative abundances of kaolinite and chlorite. "Smectite" abundance is lower than $50 \%(35 \%-50 \%, 45 \%$ on average $)$. Smectite is a minor phase $(3 \%-9.5 \%, 5.8 \%$ on average $)$.

Illite has good crystallinity $\left(0.35^{\circ}\right.$ to $\left.0.45^{\circ} 2 \theta\right)$. The ratio between the $002 / 001$ illite reflections varies between 0.35 to 0.42 . Kaolinite abundance increases up to $25 \%$, which explains the clear reflection at $62.25^{\circ} 2 \theta$ (Section 105-645E-17, Fig. 7). The basal part of facies 3 contains significant amounts of gibbsite correlated with kaolinite.

The large reflection at $60^{\circ} 2 \theta$ is indicative of the abrupt increase of chlorite content, which can be quantified ( $5 \%$ on average). The low values of the ratio between the $002+004 / 003$ chlorite reflections suggest a high magnesium content (Brindley and Brown, 1980). TCI/quartz ratio values are similar to those of the preceding facies.

\section{Facies 2}

Facies 2 (Cores $105-645 \mathrm{E}-10 \mathrm{R}$ to $-15 \mathrm{X}, 129$ to $513 \mathrm{mbsf}$ ) consists of a late Miocene to Pleistocene sequence exhibiting two important increases of ice rafting, the first above $465 \mathrm{mbsf}$ and the second above 340 mbsf (Fig. 2). The base of facies 2 is marked (Figs. 2 and 7) by an abrupt increase of mixed-layer chlorite/smectite abundance, an increase of the chlorite abundance and of the chlorite/kaolinite ratio, and a decrease of "smectite" abundance. "Smectite" abundance is lower than $45 \%(20 \%-45 \%, 35 \%$ on average). Smectite constitutes a very minor phase $(0 \%$ to $3 \%)$. The "smectite"/illite ratio allows us to divide this facies into two parts. The lower part (Cores 105$645 \mathrm{E}-10 \mathrm{R}$ to $-19 \mathrm{R})$ is characterized by a "smectite"/illite ratio similar to that of the preceding facies $(1.45-2.35,1.85$ on average) and higher mixed-layer chlorite/smectite abundances (up to $25 \%$ ). In the upper part, the "smectite"/illite ratio is more variable ( 0.35 to 1.57$)$ but generally lower ( 0.95 on average) and the mixed-layer chlorite-smectite abundances generally equal $10 \%$. The base of the lower part is marked by an abrupt decrease of TCI and TCI/quartz ratio that corresponds to a low amount of clay and very small amount of quartz silt. The upper part is marked by a decrease of the TCI/quartz ratio alone that corresponds to significant amounts of quartz silt.

The illite has poor X-ray crystallinity $\left(0.35^{\circ}\right.$ to $\left.0.70^{\circ} 2 \theta\right)$. The ratio between the $002 / 001$ illite reflections varies between
0.19 to 0.42 . The lowest value suggests a high iron content or a low potassium content (Brindley and Brown, 1980). The ratio between the $002+004 / 003$ chlorite reflections is low and suggests a high magnesium content.

\section{Facies 1}

Facies 1 (Cores 105-645B-14X to $-1 \mathrm{X}, 0$ to $129 \mathrm{mbsf}$ ) consists of sediments of Pleistocene to Holocene age. In this facies, onehalf the clays generally consist of chlorite and illite. "Smectite" and kaolinite are present in variable quantities and appear to vary in antipathy with illite and subregular mixed-layer illite/ smectite. The chlorite/kaolinite ratio is high $(0.35$ to $1.42,0.91$ on average).

TCI is the same as in facies 2 , but the TCI/quartz ratio is on average lower than in the preceding facies, which suggests the presence of small amounts of quartz silt and dilution by carbonates (Srivastava, Arthur, et al., 1987).

The ratio between the 002 and 004/003 chlorite reflections is variable but is less than 4 , which always indicates a consistently high magnesium content. The illite X-ray crystallinity slowly increases from $0.35^{\circ}$ to $0.55^{\circ} 2 \theta$. The $002 / 001$ illite reflections ratio is low (less than 0.32 ), suggesting a high iron content.

\section{GEOCHEMISTRY}

The geochemical data obtained by molecular and atomic absorption analyses and by microprobe investigations support the distinction of the same four basal mineralogical facies $\left(C_{2}\right.$ to $\left.C_{5}\right)$ previously outlined. The facies $\mathrm{C}_{1}$ was not studied by this method. The geochemical data for the $<2-\mu \mathrm{m}$ size fraction of 33 samples are given in Table 1. The concentrations of major elements and some trace elements in 10 selected bulk samples are given in Table 2. The microchemical analysis of some minerals (smectite, illite, chlorite, and kaolinite) in four samples of mineralogical facies 5 and one sample of mineralogical facies 3 are shown in Table 3.

\section{Facies 5}

From Cores 105-645E-78R to -40R, the lower part of Site 645 is characterized by the great abundances of "smectites." "Smectites" of four samples (105-645E-73R-3, 120-124 cm; -70R-2, $34-38 \mathrm{~cm}$; $-70 \mathrm{R}-5,44-48 \mathrm{~cm}$; and $-66 \mathrm{R}-2,101-103 \mathrm{~cm})$ were analyzed by microprobe (Table 2 ). All the analyzed "smectites" are dioctahedral.

The smectites from Sections 105-645E-70R-2 and 70R-3, $-67 R-1,-67 R-2,67 R-3$, and -66R-2 (Fig. 9) are siliceous and closer to theoretical montmorillonite than to theoretical beidellite. The substitutions that create a net charge deficiency in the $2: 1$ structure were found more often in the octahedral site-montmorillonite. The predominant interlayer ions are (1) either $\mathrm{Mg}^{2+}$ and $\mathrm{Na}^{+}$, (2) either $\mathrm{K}^{+}$and $\mathrm{Na}^{+}$, or (3) $\mathrm{Na}^{+}$. In Cores $105-$ 645E-70R and -66R, a second smectite (Sections 105-645E-70R-1 and 66R-1, Fig. 5) occurs. This one is less abundant and beidellitic, with $\mathrm{Mg}^{2+}$ as the predominant interlayer ion. In Core 105$645 \mathrm{E}-73 \mathrm{R}$, the analyzed "smectite" is mixed-layer illite-montmorillonite, with a tendency toward high $3 R_{2}$ (Fig. 9) content, which is not due to interlayer $\mathrm{Mg}^{2+}$, the predominant interlayer ions being $\mathrm{K}^{+}$and $\mathrm{Na}^{+}$.

Illite minerals in Core 105-645E-66R constitute an inhomogeneous group marked by an abundance of $\mathrm{Fe}_{2} \mathrm{O}_{3}$ ranging from $5.93 \%$ to $14.49 \%$. In the same sample we found iron chlorite (Fig. 9) and kaolinite relatively rich in $\mathrm{Fe}_{2} \mathrm{O}_{3}(0.97 \%$ to $4.43 \%)$ and $\mathrm{MgO}(0.49 \%$ to $2.78 \%)$ (Fig. 9). Some $\mathrm{Fe}_{2} \mathrm{O}_{3}$ and $\mathrm{MgO}$ can occur in the kaolinite layer, but most of these compounds are probably adsorbed.

The geochemistry of the $<2-\mu \mathrm{m}$ fractions is consistent with the great abundance of "smectites." In an aluminum-10 magnesium-10 potassium diagram, the corresponding points stand in a 


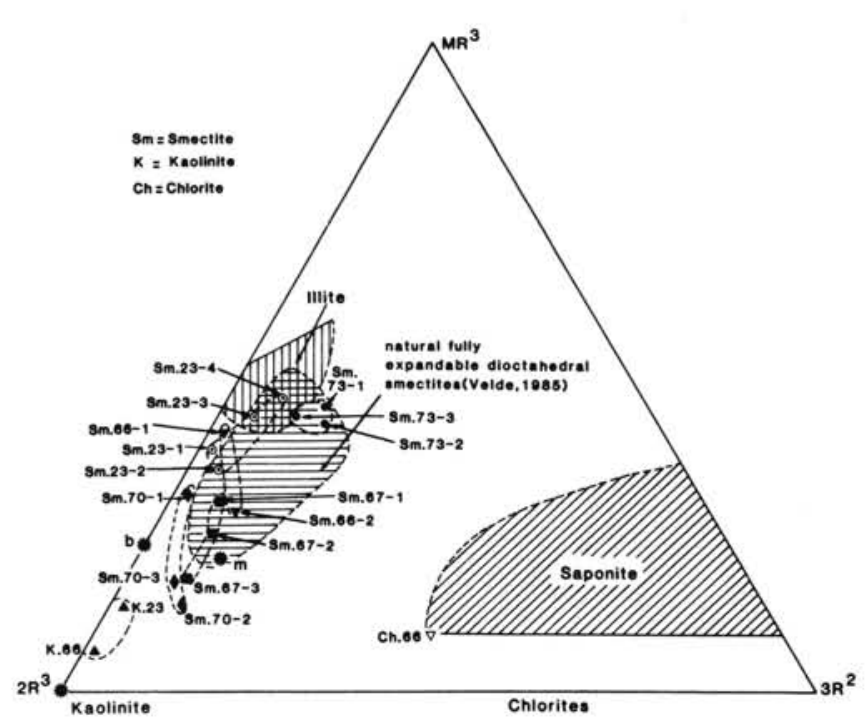

Figure 9. Chemical compositions of "smectite," kaolinite, and chlorite at Site 645 in the $M R^{3}-2 R^{3}-3 R^{2}$ coordinates (Velde, 1985). (The analysis is converted to relative atomic proportion of the element, $\mathrm{MR}^{3}=\mathrm{Na}+\mathrm{K}+2 \mathrm{Ca}, 2 \mathrm{R}^{3}=\left(\mathrm{Al}+\mathrm{Fe}^{3+}-\mathrm{MR}^{3}\right) / 2,3 \mathrm{R}^{2+}=$ $\left.\left(\mathrm{Mg}^{2+}+\mathrm{Fe}^{2+}\right) / 3\right)$.

straight line (linear melting distribution?; Fig. 10B). This alignment is determined by a strong negative correlation between the $10 \mathrm{Mg} / \mathrm{Al}$ and $\mathrm{K} / \mathrm{Mg}$ ratios. The correlation factor $r(10 \mathrm{Mg} /$ $\mathrm{Al}, \mathrm{K} / \mathrm{Mg})=-0.94$ and the corresponding regression line $(10$ $\mathrm{Mg} / \mathrm{Al}=-1.229 \mathrm{~K} / \mathrm{Mg}+2.18)$ characterize facies 5 . In the same way, a similar alignment occurs in the diagram (Fig. 11B). This alignment is determined by the strong negative correlation between the $\mathrm{Si} / \mathrm{Al}$ and $10 \mathrm{~K} / \mathrm{Si}$ ratios, with a correlation factor $r$ $(\mathrm{Si} / \mathrm{Al}, 10 \mathrm{~K} / \mathrm{Si})=-0.92$ and $a$ corresponding regression line $(\mathrm{Si} / \mathrm{Al}=-2.39010 \mathrm{~K} / \mathrm{Si}+3.07)$. These two alignments suggest that the clay assemblages of facies 5 result from the mixing of two components: a magnesium- and silicon-rich one ("smectite") and a potassium- and aluminum-rich one (illite plus kaolinite).

Thus, such correlations can be explained by the dilution or regular mixing of an illite plus kaolinite minor component by great, but varied and always dominant, amounts of moderate magnesium-montmorillonite-smectite similar to those found in Cores 105-645E-70R, -67R, and -66R (Fig. 10B).

In the aluminum-10 titanium-10 magnesium diagram (Fig. 12B), the evident positive correlation between aluminum and titanium can be explained by the connection between titanium and the kaolinite clays. The low titanium content of the analyzed kaolinite (Core 105-645E-66R, Fig. 12) suggests that much of the $\mathrm{TiO}_{2}$ is adsorbed (like $\mathrm{Fe}_{2} \mathrm{O}_{3}$ and $\mathrm{MgO}$ ). The $\mathrm{Al} / \mathrm{Ti}$ ratios are always greater than 20 , the average value in continental rocks after Boström (1970). This is also true for the corresponding total rocks (Fig. 12C).

In the log [(Mn sample/Mn shale $) /(\mathrm{Fe}$ sample/Fe shale $)]$ (Fig. 13A; Mpodozis-Marin, 1977; Steinberg and MpodozisMarin, 1978; Debrabant and Foulon, 1979), the $<2-\mu \mathrm{m}$ fractions of facies 5 are impoverished in manganese and enriched with aluminum in comparison with the shale average. The low $\log \mathrm{Fe} / \mathrm{Ti}$ values with high $\mathrm{Al}^{*}(\mathrm{Al} / \mathrm{Al}+\mathrm{Fe}+\mathrm{Mn})$ values (Fig. $14 \mathrm{~A}$ ) in the Boström (1970) diagram indicate that in the $<2-\mu \mathrm{m}$ fraction (Fig. 14A) or in the total rocks (Fig. 14B) the admixture of volcanic debris is very small, indeed negligible.

\section{Facies 4}

From Cores $105-645 E-39 R$ to $-24 R$, facies 4 is still rich in "smectites," but these fully expandable clays are dominated by mixed-layer illite-montmorillonite and are enriched with trioctahedric smectites (saponite?). The geochemistry of the corresponding $<2-\mu \mathrm{m}$ fractions is consistent with these observations. The corresponding points lie on a straight line in the aluminum-10 magnesium-10 potassium diagram (Fig. 10B) and in the silicon-aluminum-10 potassium diagram (Fig. 11B). These alignments are determined by either the strong negative correlation between the $10 \mathrm{Mg} / \mathrm{Al}$ and $\mathrm{K} / \mathrm{Mg}$ ratios (Fig. $10 ; r(10 \mathrm{Mg}$ / $\mathrm{Al}, \mathrm{K}+\mathrm{Mg})=-0.95 ; 10 \mathrm{Mg} / \mathrm{Al}=-2.55 \mathrm{~K} / \mathrm{Mg}+3.23)$ or the strong negative correlation between the $\mathrm{Si} / \mathrm{Al}$ and $10 \mathrm{~K} / \mathrm{Si}$ ratios (Fig. 11B, $r(\mathrm{Si} / \mathrm{Al}, 10 \mathrm{~K} / \mathrm{Si})=-0.92 ; \mathrm{Si} / \mathrm{Al}=-2.78$ $10 \mathrm{~K} / \mathrm{Si}+3.40)$.

As for facies 5, such correlations can be explained by the dilution or regular mixing of an illite plus kaolinite minor phase by a dominant "smectite" phase more magnesian and slightly more siliceous than that of facies 5. This magnesian "smectite" phase is probably made up of mixed-layer illite-montmorillonite similar to "smectite 73" (Figs. 9, 10B, and 11B), with a small amount of trioctahedral $\mathrm{Mg}-\mathrm{Fe}^{2+}$ smectite.

An apparent connection exists between titanium and the kaolinite clays (Fig. 12B). In the $\mathrm{Mn}^{*}=f\left(\mathrm{Al}^{*}\right)$ (Fig. 13A)and log $\mathrm{Fe} / \mathrm{Ti}=f\left(\mathrm{Al}^{*}\right.$ (Fig. 14A) diagrams, the $<2-\mu \mathrm{m}$ fractions of facies 4 are similar to those of facies 5 : impoverished in manganese and iron, enriched with aluminum in comparison with shales.

\section{Facies 3}

In facies 3 from Cores 105-645E-23R to -11R, "smectite" abundances are lower than $50 \%$ and smectites begin a minor phase. "Smectites" in Core 105-645E-23R were analyzed by microprobe and are dioctahedral "smectites." The substitution, which creates a net charge deficiency in the $2: 1$ structure, is mainly formed in the tetrahedral beidellite site. But these fully expandable phases cover a large field of variable composition from medium charge $(0.60)$ in "smectite" $23-1$ (Fig. 9) to high charge (0.83) in smectite 23-4 (Fig. 9). This fact and the X-ray data suggest that nonexpanding illitic layers are present in the samples. These "smectites" are probably mixed-layer iron-illitebeidellite, in which $\mathrm{Mg}^{2+}$ and $\mathrm{Na}^{+}$are dominant interlayer ions.

Kaolinite may be abundant (up to $25 \%$ ), with various but significant amounts of gibbsite. The kaolinite clays were analyzed by microprobe (23, Fig. 9) and are similar to those that occur in facies 5 (66, Fig. 9). These amounts of aluminum-rich minerals in the $<2-\mu \mathrm{m}$ fractions of facies 3 cause a scattering of the corresponding points toward the aluminum pole in the aluminum-10 magnesium-10 potassium and silicon-aluminum-10 potassium diagrams (Figs. 10C and 11A). The probable connection between titanium and kaolinite also occurs in facies 3 (Fig. 12A). In the $\mathrm{Mn}^{*}=f\left(\mathrm{Al}^{*}\right)$ (Fig. 13A) and $\log \mathrm{Fe} / \mathrm{Ti}=f\left(\mathrm{Al}^{*}\right)$ (Fig. 14A) diagrams, the $<2-\mu \mathrm{m}$ fractions of facies 3 are similar to those in facies 5 and 4 .

\section{Facies 2}

From Cores $105-645 \mathrm{E}-10 \mathrm{R}$ to $-15 \mathrm{X}$, facies 2 is characterized by an increase of chloritic and illitic clay abundances and progressively more abundant but significant amounts of quartz silt. "Smectite" abundances are lower than $45 \%$, and smectite can no longer be quantified.

The geochemistry of the corresponding $<2-\mu \mathrm{m}$ fractions is consistent with these observations. The corresponding points lie on a straight line in the aluminum-10 magnesium- 10 potassium diagram (Fig. 10C). This alignment is determined by the strong negative correlation between the $10 \mathrm{Mg} / \mathrm{Al}$ and $\mathrm{K} / \mathrm{Mg}$ ratios (Fig. $10 \mathrm{C} ; r(10 \mathrm{Mg} / \mathrm{Al}, \mathrm{K} / \mathrm{Mg})=-0.84 ; 10 \mathrm{Mg} / \mathrm{Al}=-1.87$ $\mathrm{K} / \mathrm{Mg}+4.03)$. Such correlations can be explained by the dilution of a "smectite" minor phase by a dominant illitic phase. 


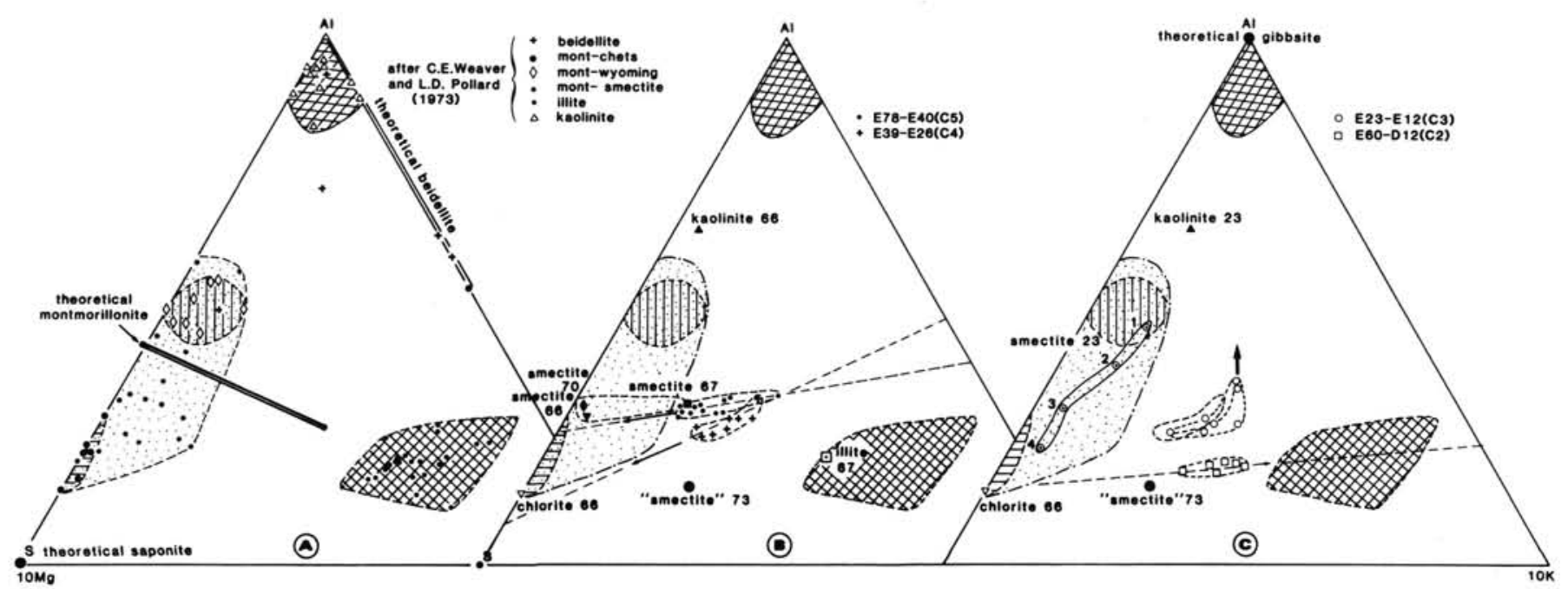

Figure 10. Chemical compositions of clay minerals and $<2-\mu \mathrm{m}$ clay fractions from selected samples of Site 645 in the aluminum-10 magnesium-10 potassium coordinates ( $\mathrm{Al}, \mathrm{Mg}$, and $\mathrm{K}$ expressed as millications in $100 \mathrm{~g}$ weight of minerals or clay fractions).

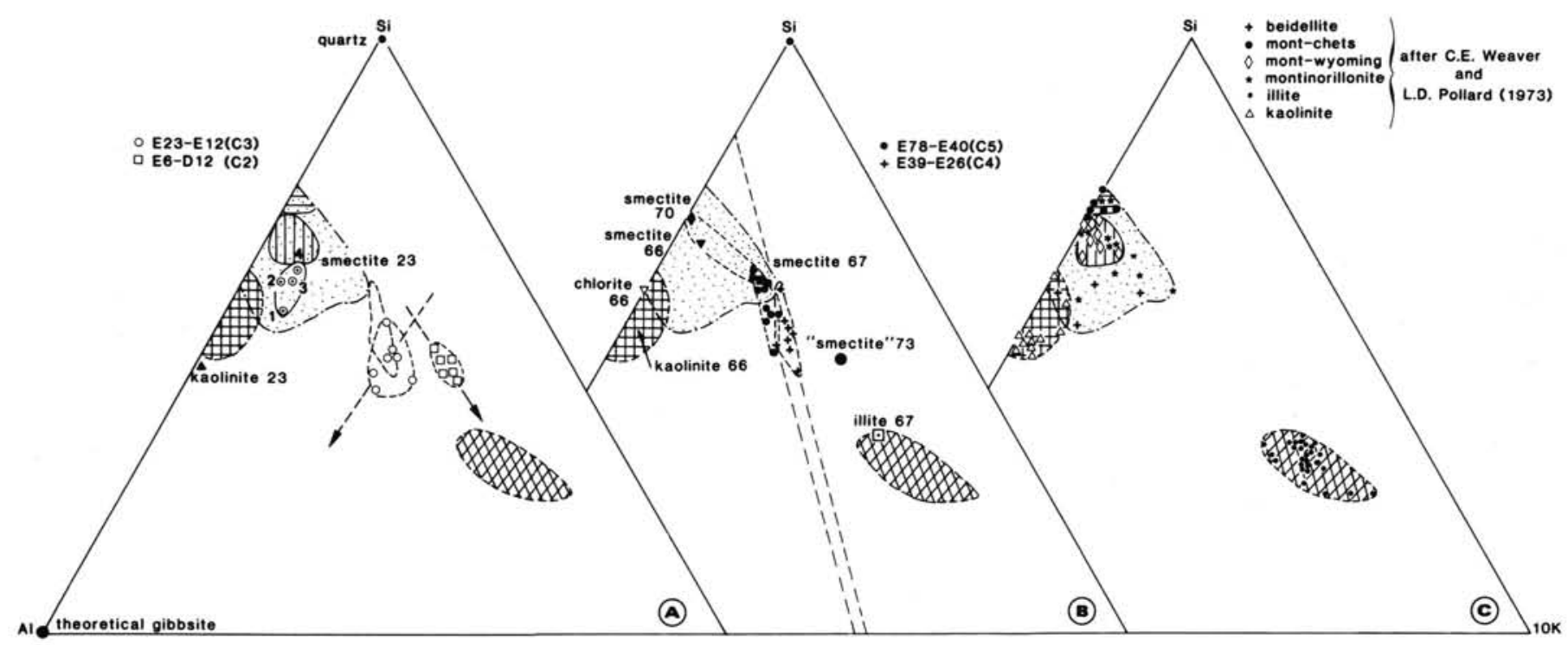

Figure 11. Chemical compositions of clay minerals and $<2-\mu \mathrm{m}$ fractions from selected samples of Site 645 in the silicon-aluminum-10 potassium coordinates with the compositional fields of kaolinite, smectite, and illite, after Weaver and Pollard (1973) (Si, Al, and K expressed as millications in 100 $\mathrm{g}$ weight of minerals or clay fractions).

This alignment is also apparent in the silicon-aluminum-10 potassium diagram and is determined by a worse negative correlation between the $\mathrm{Si} / \mathrm{Al}$ and $10 \mathrm{~K} / \mathrm{Si}$ ratios (Fig. $11 \mathrm{~A} ; r(\mathrm{Si} / \mathrm{Al}$, $10 \mathrm{~K} / \mathrm{Si})=-0.55 ; \mathrm{Si} / \mathrm{Al}=-1.2810 \mathrm{~K} / \mathrm{Si}+3.51)$. The relatively high values of the $\mathrm{Si} / \mathrm{Al}$ ratio can be explained by the significant amounts of quartz and feldspar. In the $\mathrm{Mn}^{\circ}=f\left(\mathrm{Al}^{*}\right)$ (Fig. 13A) and the $\log \left(\mathrm{Fe} / \mathrm{Ti}=f\left(\mathrm{Al}^{*}\right)\right.$ diagrams (Fig. 14), the $<2-\mu \mathrm{m}$ fractions of facies 2 are similar to those in other facies. But the corresponding points are closer to those of shale.

\section{INTERPRETATION}

Before considering the significance of the mineralogical and geochemical assemblages in the five facies identified at Site 645, we should explain briefly the possible origins of the various constituents (Millot, 1984; Biscaye, 1965; Krauskopf, 1967; Griffin et al., 1968; Paquet, 1969; Chamley, 1971; Latouche, 1971; Singer, 1984; Velde, 1985).
Illite and chlorite are the main or dominant clay minerals in facies 1 and 2. Illite, chlorite, quartz, amphiboles, as well as calcic-sodic, and alkali feldspars are present in crystalline and metamorphic rocks. These constituents have been observed frequently in the clay-size fractions and in the silt fraction of soils and sediments produced by high-latitude or cold-climate weathering. They can also result from the rejuvenation of nearby mountains by tectonism or the appearance of streams or ice sheets draining old shield areas.

Kaolinite is always present. Kaolinite may be newly formed by hydrolysis processes associated with hot and humid hydrolyzing climate. But the existence of kaolinite in both Pliocene and Quaternary sediments (in Baffin Bay sediments, Piper and Slatt, 1977; in Beaufort Sea sediments, Naidu et al., 1971; in Arctic Ocean sediments, Darby, 1975) suggests that kaolinite can also be reworked from an exposed series; in this case, its use as a paleoclimate indicator can be misleading. Kaolinite may be 


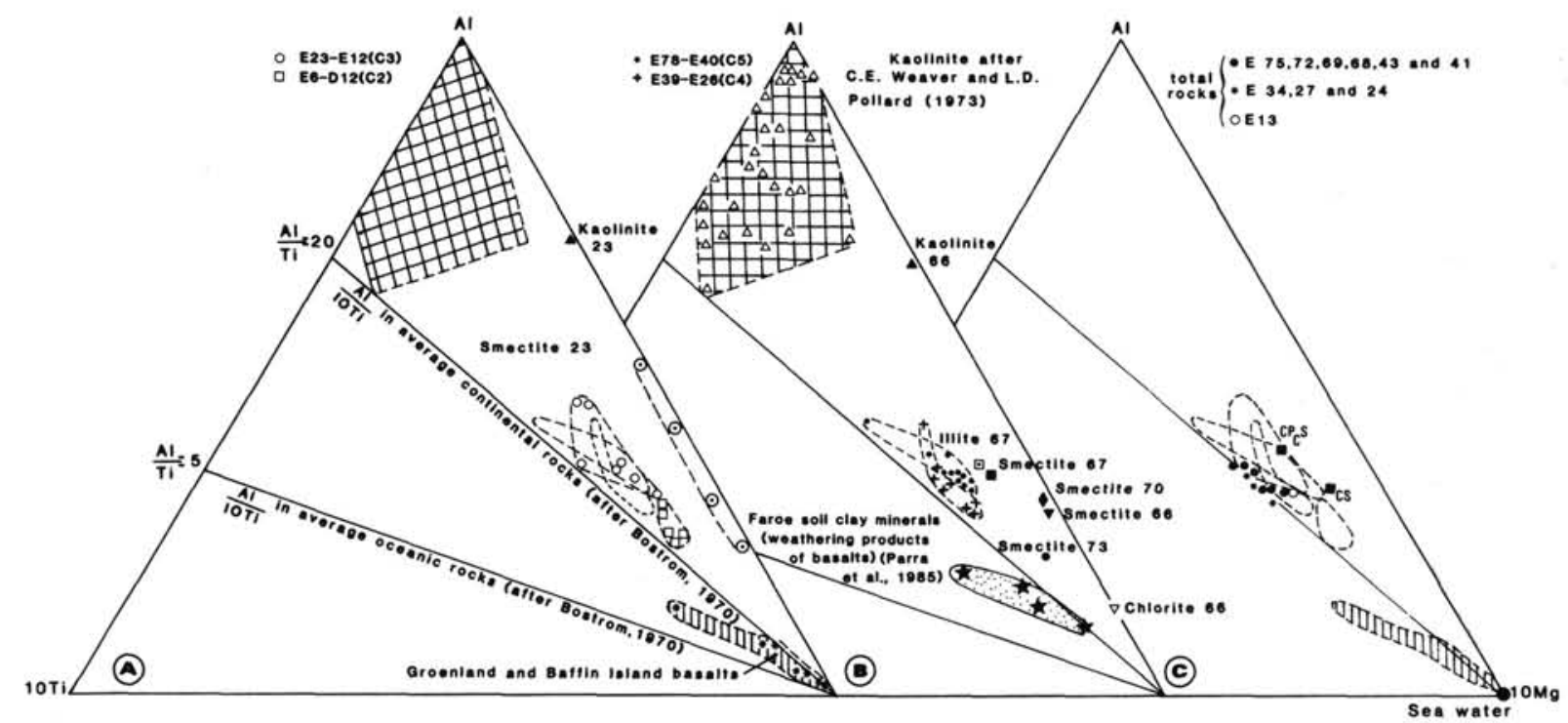

Figure 12. Chemical compositions of clay minerals, $<2-\mu \mathrm{m}$ fractions, and total rocks from selected samples of Site 645 in the aluminum-10 magnesium-10 titanium coordinates with the compositional fields of kaolinite (Weaver and Pollard, 1973), Greenland and Baffin Island basalts (Clarke, 1970), and Faroe soil clay minerals (Parra et al., 1985); Al, Mg and Ti expressed as millications in $100 \mathrm{~g}$ weight of minerals, clay fractions, or total rocks.

derived from the reworking of older, kaolinite-rich sediments or the erosion of paleosoils.

"Smectite" is the dominant clay mineral in facies 3,4 , and 5 . "Smectite" can have various origins: (1) degradation in welldrained soils in temperate-humid climates, (2) neoformation in badly drained soils under climates marked by contrast in seasonal humidity, (3) sedimentary formation in basic chemically confined environments, or (4) by aerial or submarine transformation of volcanic materials. Thus, "smectite" may be a detrital clay mineral or perhaps authigenic. The distinction between these two types of provenance is of a major importance.

In general, irregular mixed-layer chlorite-smectite clays and mixed-layer illite-smectite clays are good criteria of the continental alteration of primary clay minerals. They are detrital and develop mainly in middle latitudes. Let us now examine how these different origins can affect the Miocene to Holocene history of Site 645 .

\section{Facies 5}

The oldest deposits penetrated (Cores 105-645E-78R to -40R, early Miocene to early Pliocene-middle Miocene) are marked by abundant "smectite" in their clay fraction, with up to $70 \%$ smectite and less than $15 \%$ illite interlayers.

Such clay fractions containing up to $70 \%$ smectite may be suspected of having a significant volcanogenic component (Hein et al., 1976; Hein and Scholl, 1978; Vallier and Kidd, 1977). But the sedimentary sequence of facies 5 does not exhibit the high variability of clay mineral percentages that is characteristic of sedimentary sequences rich in authigenic-volcanogenic smectite (Hein et al., 1976).

Neither minerals or lithoclasts of volcanic origin nor ash beds occur in this facies. In the Baffin Island and West Greenland provinces, there was intense volcanic activity only during the Paleocene (Clarke and Upton, 1971). Neither the mineralogy and geochemistry of the $<2-\mu \mathrm{m}$ fractions nor that of the total rocks support a volcanogenic hypothesis. The $<2-\mu \mathrm{m}$ fractions are impoverished in manganese and iron and enriched with aluminum compared to the shale and basalt averages (Figs. 13 and 14). The $\mathrm{Al} / \mathrm{Ti}$ ratio in the $\langle 2-\mu \mathrm{m}$ fractions and total rocks is high, higher than 20 (Fig. 12), the average value in continental rocks (Boström, 1970). The $\mathrm{K} / \mathrm{Rb}$ ratio (Fig. 15) in the total rocks (Cores 105-645E-75R, -72R, -69R, -68R, -43R, and -41R) is low ( 235 to $212,224.5$ on average) and clearly lower than in Greenland and Baffin Island basalts (283 to 461,385 on average; Clarke, 1970). In contrast, the $\mathrm{K} / \mathrm{Rb}$ ratio in the total rocks of facies 5 is very near the same ratio in both shale or magmatic rock averages in the upper continental crust (Wedepohl, 1969; Fig. 15).

Similarly, if we compare the geochemistry of the analyzed smectites from clay facies 5 with that of authigenic smectites from DSDP Leg 19 bentonite beds (Hein and Scholl, 1978), we note that smectites from ODP Leg 105 have very low $\mathrm{Fe} / \mathrm{Al}$ and Ti/Al ratios (Table 4). This is why we do not favor an in-situ genesis of smectites by alteration of volcanic material. More probably, smectites are detrital minerals. They may be derived from erosion of paleosols or from the reworking of older smectite-rich sediments. If they were derived from erosion of paleosols, such "well-crystallized smectites" may indicate the prevalence of Miocene warm-climate alternations in the seasonal humidity (Chamley, 1975, 1983) during the Miocene. The pollen and spores in facies 5 reflect a coniferous boreal forest and coolto-temperate, humid climates, not a "hydrolyzing" climate. This conclusion is supported by Wolfe's (1980) recent discussion of Neogene climates at high latitudes. Here, we note "that the mean annual range of temperature during the Miocene was approximately $30^{\circ}-32^{\circ} \mathrm{C}$ and the mean annual temperature was $10^{\circ}-13^{\circ} \mathrm{C}$ at latitude $55-60^{\circ} \mathrm{N}$ and $3^{\circ}-5^{\circ} \mathrm{C}$ at latitude $70^{\circ} \mathrm{N}$." In such a cold temperate climate, weathering intensity is low; indeed, very low, "pedogenesis is relatively inactive and the soils are thin and poorly developed and characterized by a great abundance of organic matter and amorphous products and a clay fraction $<2 \%$ of the total soil" (Parra et al., 1985). Thus, chlorite, illite (inherited clays), and mixed-layer illite-smectite (relatively poor in smectite) might dominate the poor soil clay fractions that have developed on the dominant Precambrian surrounding crystalline rocks. In the same way, the higher amount of organic matter (TOC, Fig. 2) in facies 5 sediments can be explained by an important supply of terrigenous matter developed in specific climatic conditions. Then, interestingly, note that there is no obvious positive correlation between the fully ex- 

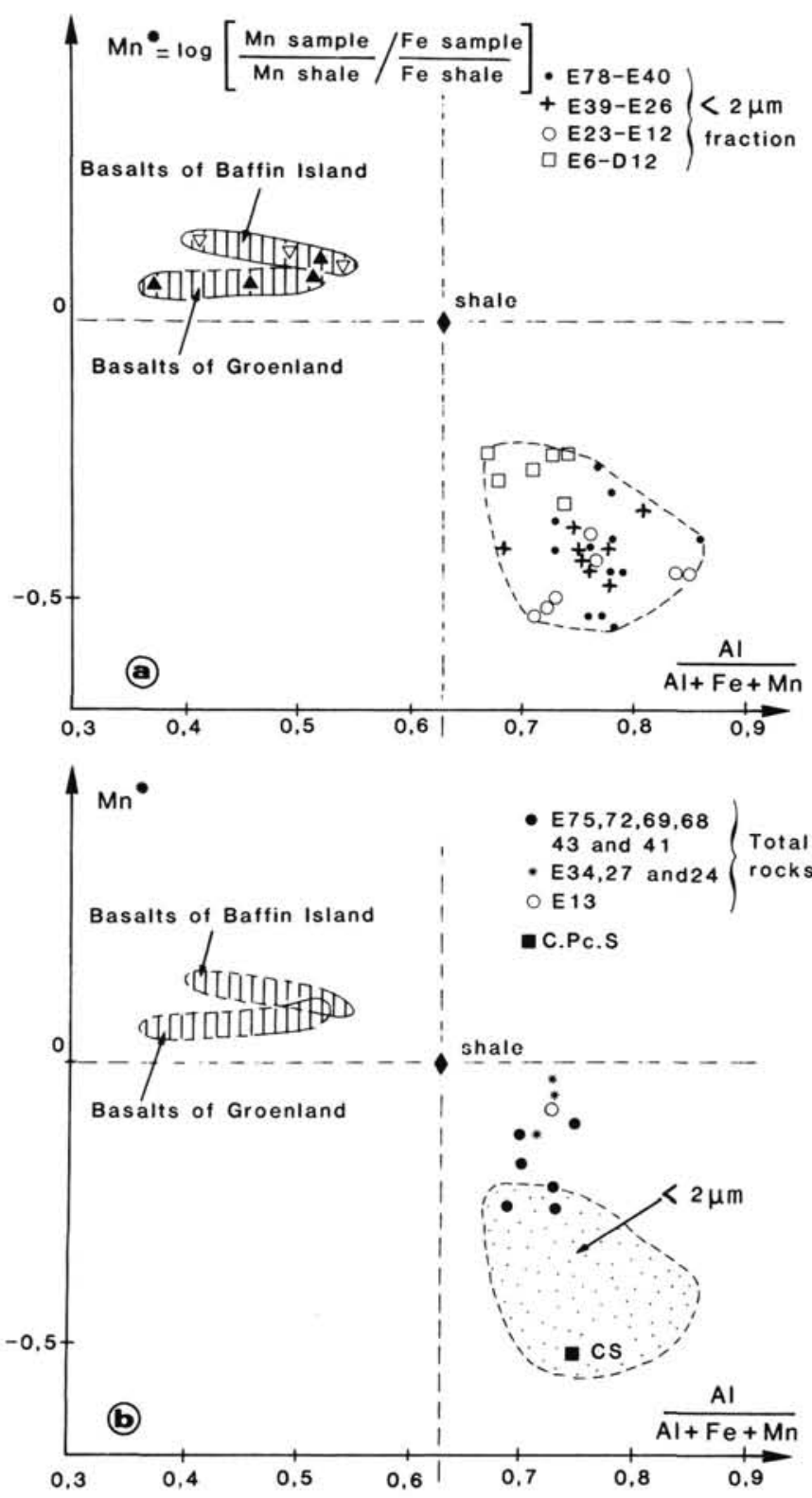

Figure 13. Chemical compositions of $<2-\mu \mathrm{m}$ fractions and total rocks from selected samples of Site 645 in the $\mathrm{Mn}^{*}-\mathrm{Al} / \mathrm{Al}+\mathrm{Fe}+\mathrm{Mn}$ coordinates (Mn, $\mathrm{Al}, \mathrm{Fe}$ expressed as parts per million) with compositional field of Baffin Island and Greenland basalts (C. Pc.S: average of statistically weighted rocks from the Canadian Shield; CS: average of rocks from the Canadian Shield, after Wedepohl, 1969).

pandable clay abundances (Fig. 2, I(001) $\left.)_{17 \mathrm{~A}} / \mathrm{I}(001)_{10 \mathrm{~A}}\right)$ and total organic carbon content (Fig. 2, TOC) but, rather, a negative one.

In such climatic conditions, another hypothesis may be that discrete smectites develop within marine environments by early diagenesis of trioctahedral smectites inherited from basalt saponites (Parra et al., 1985) (Fig. 14 and Table 5). But this explanation is geochemically as difficult as the authigenic one. Indeed, if we compare the geochemistry of the $<2-\mu \mathrm{m}$ fractions from facies 5 with the $<2-\mu \mathrm{m}$ fractions from products of weathering of tholeitic basalts (Parra et al., 1985) (Fig. 12 and Table 5), we note that the $<2-\mu \mathrm{m}$ fractions from facies 5 clearly have $\mathrm{Mg}$ / $\mathrm{Al}, \mathrm{Fe} / \mathrm{Al}, \mathrm{Ti} / \mathrm{Al}$ ratios lower than those in volcanic weathering clays. The lowering of the $\mathrm{Mg} / \mathrm{Al}$ ratio cannot possibly be the
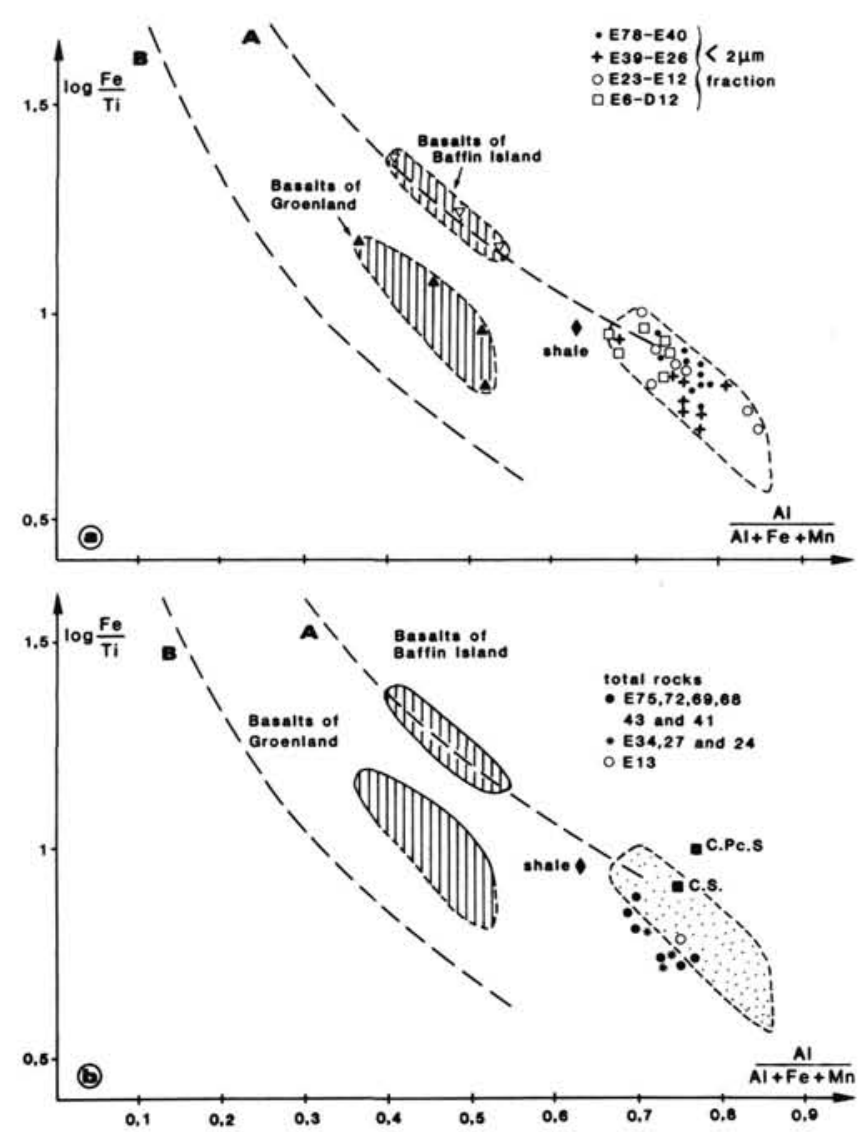

Figure 14. Chemical compositions of $<2-\mu \mathrm{m}$ fractions and total rocks from selected samples of Site 645 in the $\log \mathrm{Fe} / \mathrm{Ti}-\mathrm{Al} / \mathrm{Al}+\mathrm{Fe}+\mathrm{Mn}$ coordinates of Böstrom (1970) (C.Pc.S and C.S: see Fig. 13) (Fe, Ti, Al, and $\mathrm{Mn}$ expressed as parts per million).

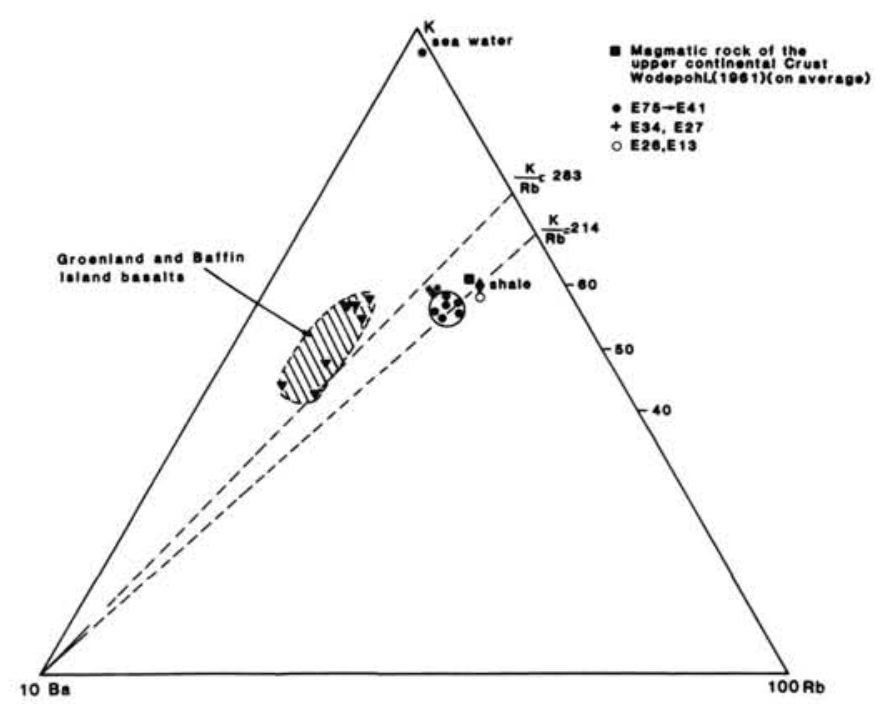

Figure 15. Chemical compositions of total rocks from selected samples of Site 645 in the potassium-10 barium $-100 \mathrm{Rb}$ coordinates $(\mathrm{K}, \mathrm{Ba}$, and $\mathrm{Rb}$ expressed as parts per million).

result of diagenesis associated with pore fluids of seawater composition because during diagenesis smectites were enriched in magnesium (Hein and Scholl, 1978). Moreover, the large abundances of dioctahedral smectite are not linked with the occurrence and abundance of trioctahedral smectite in the clay frac- 
Table 4. $\mathrm{Fe} / \mathrm{Al}$ and $\mathrm{Ti} / \mathrm{Al}$ ratios from smectities of ODP Leg 105 and DSDP Leg 19, average magmatic rocks and Baffin Bay basalts (Clarke, 1970).

\begin{tabular}{|c|c|c|c|}
\hline & Samples & $\mathrm{Pe} / \mathrm{Al}$ & $\mathrm{Ti} / \mathrm{A} 1$ \\
\hline 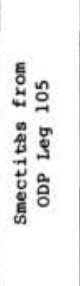 & $\begin{array}{l}645-\mathrm{E} 70-02,34-38 \\
645-\mathrm{B} 67-05 \\
645-\mathrm{B} 66-02,101-103\end{array}$ & $\begin{array}{l}0.11 \\
0.19 \\
0.40 \\
0.31 \\
0.23 \\
9.16 \\
0.14 \\
0.19\end{array}$ & $\begin{array}{c}0 \\
0.006 \\
0.007 \\
0.026 \\
0.019 \\
0.006 \\
0 \\
0.06\end{array}$ \\
\hline 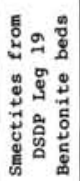 & $\begin{array}{ll}184-B 1-01, & 120-121 \\
184-B 5-02, & 22-24 \\
189-11-02, & 09-13 \\
192-A 2-03, & 83-85 \\
192-A 5-01, & 05-06\end{array}$ & $\begin{array}{l}0.54 \\
0.47 \\
0.33 \\
0.44 \\
1.07\end{array}$ & $\begin{array}{l}0.12 \\
0.13 \\
0.13 \\
0.15 \\
0.29\end{array}$ \\
\hline 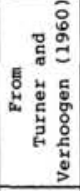 & $\begin{array}{l}\text { Aug. rhyolite } \\
\text { Aug. andesite } \\
\text { Aug. basalt }\end{array}$ & $\begin{array}{l}0.25 \\
0.52 \\
1.05\end{array}$ & $\begin{array}{l}0.02 \\
0.05 \\
0.10\end{array}$ \\
\hline 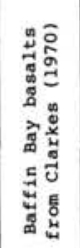 & $\begin{array}{l}\text { Picritic basalt, Baffin Island } \\
\text { Picritic basalt, Svartenhuk } \\
\text { olivine basalt, Baffin Island } \\
\text { olivine basalt, Svartenhuk } \\
\text { olivine poor basalt, Baffin Island } \\
\text { olivine poor basalt, Svartenhuk } \\
\text { Feldspar phyric basalt, Svartenhuk }\end{array}$ & $\begin{array}{l}1.40 \\
1.64 \\
1.02 \\
1.15 \\
0.82 \\
0.88 \\
0.90\end{array}$ & $\begin{array}{l}0.06 \\
0.11 \\
0.05 \\
0.09 \\
0.06 \\
0.09 \\
0.13\end{array}$ \\
\hline
\end{tabular}

tion at Site 645 . In facies 4 , the relative abundance of these trioctahedral smectites increases, while the abundance of dioctahedral smectite abruptly decreases.

This is why, for the "smectite"-rich sediments of facies 5 at Site 645 , we favor an origin by the reworking of older smectiterich sediments. Possible northern sources of smectites are Ellesmere Island sediments or offshore Upper Cretaceous and Cenozoic (Paleogene, Eocene) strata (Marlowe, 1969; Boyd and Piper, 1976; Piper and Slatt, 1977; Miall, 1982).

Facies 5 corresponds to lithologic Subunits IIIB and IIIC. Their lithostratigraphic interpretation suggests that they were deposited beneath geostrophic bottom currents, with a greater velocity during deposition of Subunit IIIC. This vigorous southward bottom current eroded off shore Upper Cretaceous and $\mathrm{Ce}$ nozoic strata and transport the detritus to the site. Thus, the great abundances of smectite in the $<2-\mu \mathrm{m}$ fractions may be the result of reworking of these older smectite-rich sediments.

Illite, mixed-layer illite-smectite (poor in amectite) and mixedlayer chlorite-smectite were probably inherited clays from paleosols, older sediments, or rocks. Kaolinite was reworked from older kaolinite-rich sediments or sedimentary rocks. Some positive correlation between illite plus kaolinite relative abundance and detrital organic carbon content (TOC, Fig. 2) suggests that the distribution of these clays may be associated with another provenance (continental?) and another process for their introduction into the basin than that of the smectite clays. For example, the former clays could have been deposited on the slope ei-
Table 5. $\mathrm{Mg} / \mathrm{Al}, \mathrm{Fe} / \mathrm{Al}$ and $\mathrm{Ti} / \mathrm{Al}$ ratios from $<2 \mu \mathrm{m}$ fractions of selected samples of Site 645 and from $<2 \mu \mathrm{m}$ fractions of Faroe soils from Parra et al. (1985).

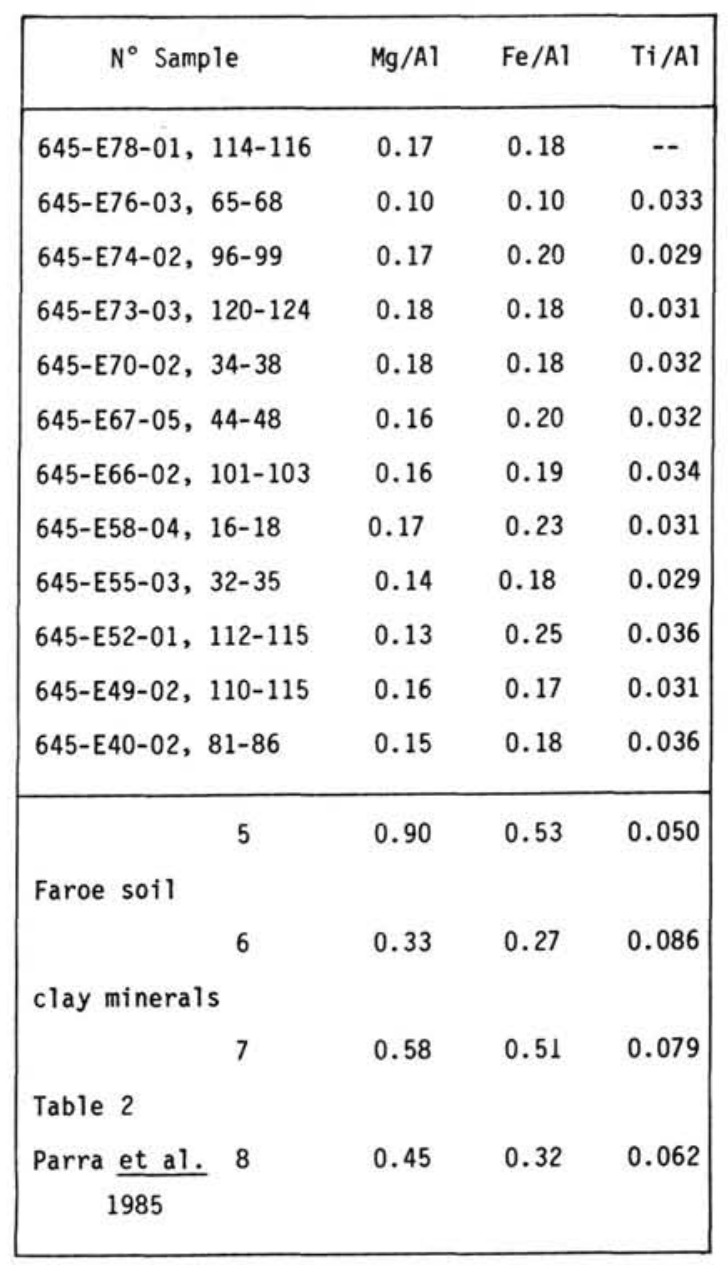

ther after large storms on the shelf had sent plumes of suspended sediment into deep water or by turbiditic current. But, in any case, they were mixed with "smectite" in particle-rich, deep-water layers subjected to a vigorous southward bottom current. Then, the antithetic relationship between "smectite" and illite plus kaolinite relative abundances and the associated regular geochemical variations (Figs. 10 and 11) can be explained by (1) size sorting during bottom current transport, (2) preferential transport of smectite, or (3) fluctuations in the speed of the bottom current.

The minor trioctahedral smectites may be the weathering products of basaltic rocks that outcrop to the south or to the east (Fig. 1). Perhaps these were transported to the site by surface current.

\section{Facies 4}

The deposits of facies 4 (Cores 105-645E-39R to -24R; early Pliocene to middle Miocene) are different from those of facies 5 by a net decrease of the "smectite" clay abundances, by qualitative and geochemical changes in the illite-smectite clay assemblages (Figs. 10 and 11), and by an abrupt increase of kaolinite abundance in their lower portions.

Such modifications can be explained by changes in source areas and transport processes. The great abundances of mixedlayer illite-smectite in the "smectite" clays and their high alumi- 
num content (Figs. 13 and 14) may be good criteria of their detrital origin from either (podzol?) paleosols or old sediments. The parallel increase of illite and subregular mixed-layer illitesmectite, a certain correlation between expandable clay abundances, and detrital organic carbon contents (Fig. 2) allows us to propose a continental detrital origin.

Kaolinite was inevitably derived from the reworking of older kaolinite-rich sediments. The abrupt variations of the kaolinite abundances and the occurrence of few graded beds suggests that turbidity currents were partly responsible for the introduction of sediments with kaolinite into the basin. Then, bottom-current transport may have been periodically overwhelmed by downslope transport of mud turbidites from the shelf edge. Poorly consolidated Mesozoic or Paleogene sandstones and shales on the nearby shelves of Ellesmere Island, Baffin Island, or Greenland (Fig. 1) may be a potential source for the detritus in facies 4 .

Our grain-size study suggests that after introduction into the basin, these sediments were always subjected to bottom currents, with the same results as those for facies 5. An increased influx of sediments from the Westen Greenland shelf (?) can explain the relative increase of volcanogenic trioctahedral smectites, which may be the weathering products of tholeitic basalts outcropping in West Greenland (Fig. 1).

\section{Facies 3}

The sediments of facies 3 (Cores 105-645E-23R to -11R), late Miocene to early Pliocene) are characterized by the first granitic pebble (Core 105-645E-19R) and the first occurrence of amphibole in the silt fraction. The clay fraction is marked by a net decrease in "smectite" abundance and by an increase of kaolinite, illite, and chlorite abundances. This relatively abundant kaolinite is linked with significant amounts of gibbsite. Such modifications can be explained by changes in sources areas, in climate, and in transport processes.

The occurrence of amphibole and the abrupt increase of chlorite abundance suggest the appearance of streams, valley glaciers, or piedmont glaciers draining old crystalline and metamorphic rocks. Much of the clays of facies 3 may be derived from the erosion of continental rocks. The great abundance of gibbsite linked with kaolinite implies that kaolinite could not be formed by hydrolysis processes during the deposition of facies 3 , but was inevitably reworked from kaolinite-rich sedimentary rocks. The geographic distribution of the sedimentary rock outcrops (Fig. 1) and the occurrence of some important concentrations (up to $60 \%$ ) of kaolinite in recent sediments of the Kane Basin point to a northern source, for example Paleozoic or Lower Cretaceous beds in Ellesmere Island (Kravitz, 1982). But kaolinite might also be derived from erosion of submerged coastal-plain strata (Piper and Slatt, 1977). The other clays also have a terrigenous origin from paleosoils or sedimentary crystalline rocks. The net decrease of "smectite" abundance and of the smectite content in mixed-layer illite-smectite (Fig. 7) can be explained by an important cooling and the decline of the conditions favoring hydrolysis.

Thus, the clay modification at the base of facies $3(630 \mathrm{mbsf}$, $9.3 \mathrm{Ma}$ ) could be correlated with an important climatic change that produced a net increase of the continental alteration processes. Such a phenomenon could be correlated with the beginning of glacial processes on the continent. This hypothesis is supported by an important grain-size modification that exists just above ( $600 \mathrm{mbsf}, 8.3 \mathrm{Ma}$ ) and could be correlated with the beginning of glacial processes in Baffin Bay, that is, the growth of an ice tongue from valley glaciers, the expansion of ice shelf, the beginning of iceberg calving, and ice rafting.

That these two sedimentological changes were separated by some time ( $\sim 1$ m.y.) can be explained by either (1) a slow, gradual buildup of mountain ice sheets and of the ice shelf or (2) the deposition of the coarser ice-rafted sediments in the area well inland of Site 645 , during the sedimentation of the basal part of the facies 3 .

This latter explanation can explain why plutonic pebbles are absent in the basal part of facies 3 and are rare above. Indeed, during the deposition of the basal part of facies 3 , the development of the ice sheet should have been moderate. The calving line might be well inland of Site 645 , and the buoyancy line even more so. Most of the sediments rafted out were deposited during basal melting seaward of, but near, the buoyancy line (Boulton, 1972), while the coarser ice-rafted sediments were restricted to the part of the continental margin closely adjacent to the continent. The finer ice-rafted sediments alone might have been transported as suspended particles to the outer part of the continental margin.

Our grain-size study suggests that three processes may explain the transport of these continental inherited clays to the deposition site: (1) ice rafting, (2) turbidity currents, and (3) bottom current. But even turbidity current influence cannot be ruled out as the main transport process was always a strong bottom current.

\section{Facies 2}

The sediments of facies 2 (Cores 105-645E-10R to 105-645B15X; Pleistocene to late Miocene) exhibit important increases of ice rafting. The first one, upward to 465 mbsf ( 3.5 m.y. BP) suggests an important increase in the buildup of the mountain ice sheet and of the ice shelf during early Pliocene. Thus, the suite of facies 2 is a glacial stage. This hypothesis is supported by the following:

1. An abrupt and large increase of detrital contribution (chlorite, illite, kaolinite, quartz, amphibole, and feldspar) from crystalline and old sedimentary rocks and from moderately altered continental deposits (irregular mixed-layer clays, "smectite"-poor in smectite layers) (Fig. 7). Chlorite plus illite plus kaolinite constitute one-half the clay fraction, upward to $520 \mathrm{mbsf}$ ( $\sim 5$ m.y. BP) (Fig. 1).

2. The evidence of significant ice rafting that occured in central Arctic Ocean sediments paleomagnetically dated at $\sim 4.5$ m.y. BP (Herman, 1970; Herman and Hopkins, 1980; Margolis and Herman, 1980).

The second increase of ice rafting, upward to $340 \mathrm{mbsf}$ ( 2.5 m.y. BP) coincides with a major oceanographic and climatic change observed in sediment cores from the Central Arctic Ocean (Herman and Hopkins, 1980). This change is characterized by "a great increase in the frequency and intensity of glaciation on adjoining land masses" (Herman and Hopkins, 1980) and the development of a seasonal ice cover.

The clay mineral content also exhibits cycles defined by antithetic variations of illite and "smectite" abundances. But in the absence of biogenic components, it was impossible to decide if this cyclicity was climatically controlled. This cyclicity may have been controlled by transport processes, such as those for the sandier interval around 270 mbsf, enriched in "smectite" and probably deposited under the influence of bottom currents.

\section{Facies 1}

The deposits of facies 1 (Cores 105-645B-14X to -1X; late Pliocene to Holocene) are characterized by a net decrease of clays inherited from moderately altered continental deposits (irregular mixed-layer clays and "smectite"). The clay contribution from crystalline or old sedimentary rocks (chlorite, illite, subregular mixed-layer illite-smectite, kaolinite) constitutes more than $60 \%$ of the clay fraction (Fig. 2). Examination of the X-ray diffractograms reveals (Fig. 3) a significant quartz component 
(low TCI/quartz ratio with a high clay content, Fig. 3). During facies 1 deposition, ice rafting was the dominant control for sedimentation. This control explains the high clay content linked with the high proportion of particles coarser than $250 \mu \mathrm{m}$.

The base of facies 1 occurs at $126 \mathrm{mbsf}(\sim 0.95 \mathrm{Ma})$, and it may be correlated with the boundary between Units II and I (between 0.9 and $0.7 \mathrm{Ma}$ ) defined in sediment cores from the central Arctic Ocean (Margolis and Herman, 1980; Herman and Hopkins, 1980). This boundary may record another climatic threshold. At that time, the temperature of the water decreased to its present levels and the perennial Arctic ice pack probably originated. This seems to coincide "with the initiation of a pattern of frequent glacial-deglacial cycles at middle latitudes" (Herman and Hopkins, 1980). These continental climatic changes favored direct erosion of rocks during the glacial stage and some moderate alteration during the deglacial stage.

The clay mineral content exhibits some cycles defined by antithetic variations of illite and either "smectite" or kaolinite abundances. But the number of samples is too low to reflect the real cyclic nature of those sediments.

\section{CONCLUSIONS}

Interpretation of regional seismic lines, sedimentary textures and structures, clay mineralogy, and $<2-\mu \mathrm{m}$ geochemistry suggest an unexpectedly pronounced but variable influence of southward, deep, "contour-following" currents during deposition of Miocene sediments (630 to 1147 mbsf) in western Baffin Bay. These features indicate that Baffin Bay was probably a main conduit between the Arctic and Atlantic oceans, and that the bay was the focus of southward-directed flow of arctic water masses to the Labrador Sea from at least the early middle Miocene (Srivastava, Arthur, et al., 1987). All clay assemblages are detrital from old sedimentary rocks or moderately altered continental deposits. The characteristics and the changes in the clay assemblages can be explained by size sorting, preferential transport of smectite, fluctuations of the speed of bottom currents, and changes in source areas. An important modification occurs at $630 \mathrm{mbsf}$ (clay fraction) or $600 \mathrm{mbsf}$ (sedimentary textures) that can be explained by the beginning of glacial processes on the continent $(630 \mathrm{mbsf}, \sim 9 \mathrm{Ma})$ and the onset of ice rafting in Baffin Bay (600 mbsf, $\sim 8 \mathrm{Ma})$. We conclude (see Srivastava, Arthur, et al., 1987) that glaciation in Baffin Bay may have begun earlier than in the northwestern Atlantic ( 2.3-2.4 Ma, Zimmerman et al.; $2.4-2.55 \mathrm{Ma}$, Ruddiman et al., 1987). But the onset of major glacial ice rafting in Baffin Bay was at about 460 mbsf $(\sim 3.4 \mathrm{Ma})$, with a maximum at 400 mbsf and important fluctuations above that depth. Above $600 \mathrm{mbsf}$, clay assemblages are detrital and inherited from crystalline rocks or old sedimentary rocks. The characteristics and the changes in clay assemblages can be explained mainly by the fluctuations of climate and ice rafting but also by fluctuations of the speed of weak (?) bottom currents and perhaps by supply from mud turbidite currents.

\section{REFERENCES}

Andrews, J. T., 1885. Grain-size characteristics of quaternary sediments, Baffin Island region. In Andrews, J. T. (Ed.), Quaternary Environments, Eastern Canadian Artic, Baffin Bay and Western Greenland: Winchester, MA (Allen and Unwin), 5:125-153.

Aksu, A. E., 1983. Holocene and Pleistocene dissolution cycles in deepsea cores of Baffin Bay and Davis strait: paleoceanographic implications. Mar. Geol., 53:331-348.

Biscaye, P. E., 1965. Mineralogy and sedimentation of recent deep-sea clay in the Atlantic ocean and adjacent seas and oceans. Geol. Soc. Am. Bull., 76:803-832.

Boulton, G. S., 1972. Role of thermal regime in glacial sedimentation. Inst. Br. Geogr. Spec. Publ., 4:1-19.

Boyd, R. W., and Piper, D.J.W., 1976. Baffin Bay continental shelf clay mineralogy. Mar. Sediments, 12(1):17-18.
Böstrom, K., 1970. Submarine volcanism as a source for iron. Earth Planet. Sci. Lett., 8:348-354.

Brindley, G. W., and Brown, G., 1980. Crystal structures of clay minerals and their X-ray identification. Mineral. Soc. London, Mono. 5.

Chamley, H., 1971. Recherches sur la sédimentation argileuse en Méditerranée. Sci. Géol., Mém. 35:1-208.

, 1975. Sédimentation argileuse en Mer Tyrrhénienne au PlioPléistocène d'aprés l'étude du Forage Joides, 132. Bull. Groupe Fr. Argiles, 27:97-137.

1983. Indications paléoclimatiques fournies par les successions argileuses du Néogène méditerranéen. Géol. Médit., 7:25-34.

Choubert, G., and Faure-Muret, A. (General Co-ordinators); Churkin, M. (Continental Co-ordinator); and Johnson, L. (Oceanic Co-ordinator), 1983. Geological World Atlas, Sheet 19.

Clarke, D. B., 1970. Tertiary basalts of Baffin Bay: possible primary magma from the mantle. Contr. Mineral. Petrol., 25:203-224.

Clarke, D. B., and Upton, B. G., 1971. Tertiary basalts of Baffin Island: field relations and tectonic setting. Can. J. Earth Sci., 8:248258.

Darby, D. A., 1975. Kaolinite and other clay minerals in Arctic ocean sediments. J. Sediment. Petrol., 45:272-279.

Debrabant, P., and Foulon, J., 1979. Expression géochimique des variations du paléoenvironnement depuis le Jurassique supérieur sur les marges nord-atlantiques. Oceanol. Acta, 2:469-476.

Debrabant, P., Delbart, S., and Lemaguer, D., 1985. Microanalyses géochimiques de minéraux argileux de sédiments prélevés dans l' Atlantique nord (Forages du DSDP). Clay Minerals, 20:125-145.

Fillon, R. H., Miller, G. H., and Andrews, J. T., 1981. Terrigenous sand in Labrador sea hemipelagic sediments and paleoglacial events on Baffin Island over the last 100000 years. Boreas, 10:107-124.

Gradstein, F. M., and Srivastava, S. P., 1980. Aspects of Cenozoic stratigraphy and paleoceanography of the Labrador Sea and Baffin Bay. Palaeogeogr., Palaeoclimatol., Palaeoecol., 30:261-295.

Griffin, J. J., Windom, H., and Goldberg, E. D., 1968. The distribution of clay minerals in the world ocean. Deep-Sea Res., 15:433-459.

Gonthier, E., Faugeres, C., and Stow, D.A.V., 1984. Contourite facies of the Faro drift, Gulf of Cadiz. In Stow, D.A.V., and Piper, D.J.W. (Eds.), Fine-Grained Sediments: Deep Water Processes and Facies. Geol. Soc. London Spec. Publ., 15:275-292.

Hein, J. R., and Scholl, D. W., 1978. Diagenesis and distribution of late Cenozoic volcanic sediment in the southern Bering Sea. Bull. Geol. Soc. Am., 8:197-210.

Hein, J. R., Scholl, D. W., and Gutmacher, C. E., 1976. Diagenesis of Neogene diatomaceous sediment from the far northwest Pacific and southern Bering Sea. Geol. Soc. Am.(Abstract with Programs), 9: 379-380.

Herman, Y., 1970. Arctic paleoceanography in late Cenozoic time. Science, 169:474-477.

Herman, Y., and Hopkins, D. M., 1980. Arctic oceanic climate in late Cenozoic time. Science, 209:557-562.

Holtzapffel, T., 1985. Les minéraux argileux. Préparation, analyse diffractométrique et détermination. Soc. Géol. Nord Publ., 12:1-136.

Kravitz, J. H., 1982. The $<2-\mu \mathrm{m}$ fraction of some high arctic glacial and glacial marine sediments. In Embry, A. F., and Balkwill, H. R., Arctic Geology and Geophysics. Can. Soc. Pet. Geol. Mem., 8:297307.

Krauskopf, K. B., 1967. Introduction to Geochemistry: New York (McGraw Hill).

Kubler, B., 1968. Evaluation quantitative du métamorphisme par la cristallinité de l'illite. Bull. Centre Rech., Pau SNPA, 2(2):385-397.

Latouche, C., 1971. Les argiles des bassins alluvionaires aquitains et des dépendances océaniques. Contribution à l'étude d' un environnement (Thesis). University of Bordeaux.

Mac Lean, B., 1978. Marine Geological-Geophysical investigations in 1977 of the Scott Inlet and Cape Dyer. Frobisher Bay areas of the Baffin Island continental shelf. Can. Geol. Surv. Pap., 78-1B:13-20. 1979. Geological-Geophysical studies in Baffin Bay and Scott Inlet-Buchan Gulf and Cape Dyer-Cumberland Sound areas of the Baffin Island Shelf. Geol. Surv. Can. Pap., 79-1B:231-244.

Mac Lean, B., and Falconer, R.K.H., 1977. Baffin Island shelf-shallow corehole drilling, 1976. Geol. Surv. Can. Pap., 77-1B:125-127.

Margolis, S.V., and Herman, Y., 1980. Northern Hemisphere sea-ice and glacial development in the late Cenozoic. Nature, 286:145-149.

Marlowe, J. I., 1969. A succession of Tertiary strata off Nova Scotia, as determined by dredging. Can. J. Earth Sci., 6:1077-1094. 
Miall, A. D., 1982. Tertiary sedimentation and tectonics in the Judge Daly Basin, northeastern Ellesmere Island, Arctic. Can. Geol. Surv. Pap., 2-8B:30.

Millot, G., 1964. Géologie des Argiles: Paris (Masson Edit.).

Mpodozis-Marin, C., 1977. Etude géologique de la région d'Agrapha (zone du Pinde-Evritanie, Grèce). Essai de classification géochimique des sédiments hypersiliceux marins, application á l'étude des formations radiolaritiques du Pinde (Thesis). University of Paris VI.

Naidu, A. S., Burrell, D. C., and Hood, D. W., 1971. Clay mineral composition and geologic significance of some Beaufort Sea sediments. J. Sed. Petrol., 41:691-694.

Paquet, H., 1969. Evolution géochimique des minéraux argileux dans les altérations et les sols des climats méditerraneéns. Mem. Serv. Carte Géol. Alsace-Lorraine (Strasbourg), 30:1-210.

Parra, M., Delmont, P., Ferragne, A., Latouche, C., Pons, J. C., and Puechmaille, C., 1985. Origin and evolution of smectites in recent marine sediments of the NE Atlantic. Clay Minerals, 20:335-346.

Pierce, J. W., and Stanley, D. J., 1975. Suspended sediment concentration and mineralogy in the central and western Mediterranean and mineralogical comparison with bottom sediments. Mar. Geol., 19: M15-M25.

Pinta, M., 1971. Spectrométrie d' Absorption Atomique: Paris (Masson Edit.).

Piper, J. W., and Slatt, R. M., 1977. Late Quaternary clay-mineral distribution of the eastern continental margin of Canada. Bull. Geol. Soc. Am., 88:267-272.

Reynolds, R. C., and Hower, J., 1970. The nature of interlayering in mixed-layer illite-montmorillonites. Clays and Clay Minerals, 18: 25-36.

Ruddiman, W. F., Backman, J., Baldauf, J., Hooper, P., Heigwin, L., Miller, K., Raymo M., and Thomas, E., 1987. Leg 94 paleoenvironmental synthesis. In Ruddiman, W. F., Kidd, R. B., Thomas, E., et al., Init. Repts. DSDP, 94: Washington (U.S. Govt. Printing Office), 1207-1215.

Singer, A., 1980. The paleoclimatic interpretation of clay minerals in soils and weathering profiles. Earth Sci. Rev., 15:303-327. 1984. The paleoclimate interpretation of clay minerals in sediments-a review. Earth Sci. Rev., 21:251-293.

Srivastava, S. P., Arthur, M., et al., 1987. Proc. ODP, Init. Repts., 105: College Station, TX (Ocean Drilling Program).
Srodon, J., 1980. Precise identification of illite/smectite interstratification by X-ray powder diffraction. Clays and Clay Minerals, 28:401411.

1984. Mixed-layer illite/smectite in low-temperature diagenesis: data from the Miocene of the Carpathian foredeep. Clay Minerals, 19:205-215.

Steinberg, M., and Mpodozis-Marin, C., 1978. Classification géochimique des radiolarites et des sédiments siliceux océaniques, signification paléo-océanographique. Oceanol. Acta, 1:359-367.

Vallier, T. L., and Kidd, R. B., 1977. Volcanogenic sediments in the Indian Ocean. In Heirtzler, J. R. (Ed.), Indian Ocean Geology and Biostratigraphy: Washington (Am. Geophys. Union), 87-118.

Velde, B., 1985. Clay Minerals. A Physico-Chemical Explanation of Their Occurrence. Developments in Sedimentology, 40: Amsterdam (Elsevier).

Weaver, C. E., and Pollard, L. D., 1973. The Chemistry of Clay Minerals. Developments in Sedimentology, 15: Amsterdam (Elsevier).

Wedepohl, K. H., 1969. Composition and abundance of common igneous rocks. Composition and abundance of sedimentary rocks. In Wedepohl, K. H. (Ed.), Handbook of Geochemistry: Berlin-Heidelberg (Springer-Verlag), Vol. 1:227-271.

Wolfe, J. A., 1980. Tertiary climates and floristic relationships at high latitudes in the Northern Hemisphere. Palaeogeogr., Palaeoclimat., Palaeoecol., 30:313-323.

Zimmerman, H., 1984. Lithostratigraphy and clay mineralogy of the western margin of the Rockall Plateau and the Hatton sediment drift. In Roberts, D. G., Schnitker, D., et al., Init. Repts. DSDP, 81: Washington (U.S. Govt. Printing Office), 683-693.

Zimmerman, H. B., Shackleton, N. J., Backman, J., Kent, D. V., Baldauf J., Kalatenback, A. J., and Morton, A. C., 1984. History of Plio-Pleistocene climate in the northeastern Atlantic, Deep Sea Drilling Project Hole 552A. In Roberts, D. G., Schnitker, D., et al., Init. Repts. DSDP, 81: Washington (U.S. Govt. Printing Office), 861-875.

Date of initial receipt: 6 May 1987.

Date of acceptance: 12 April 1988

Ms 105B-111 